
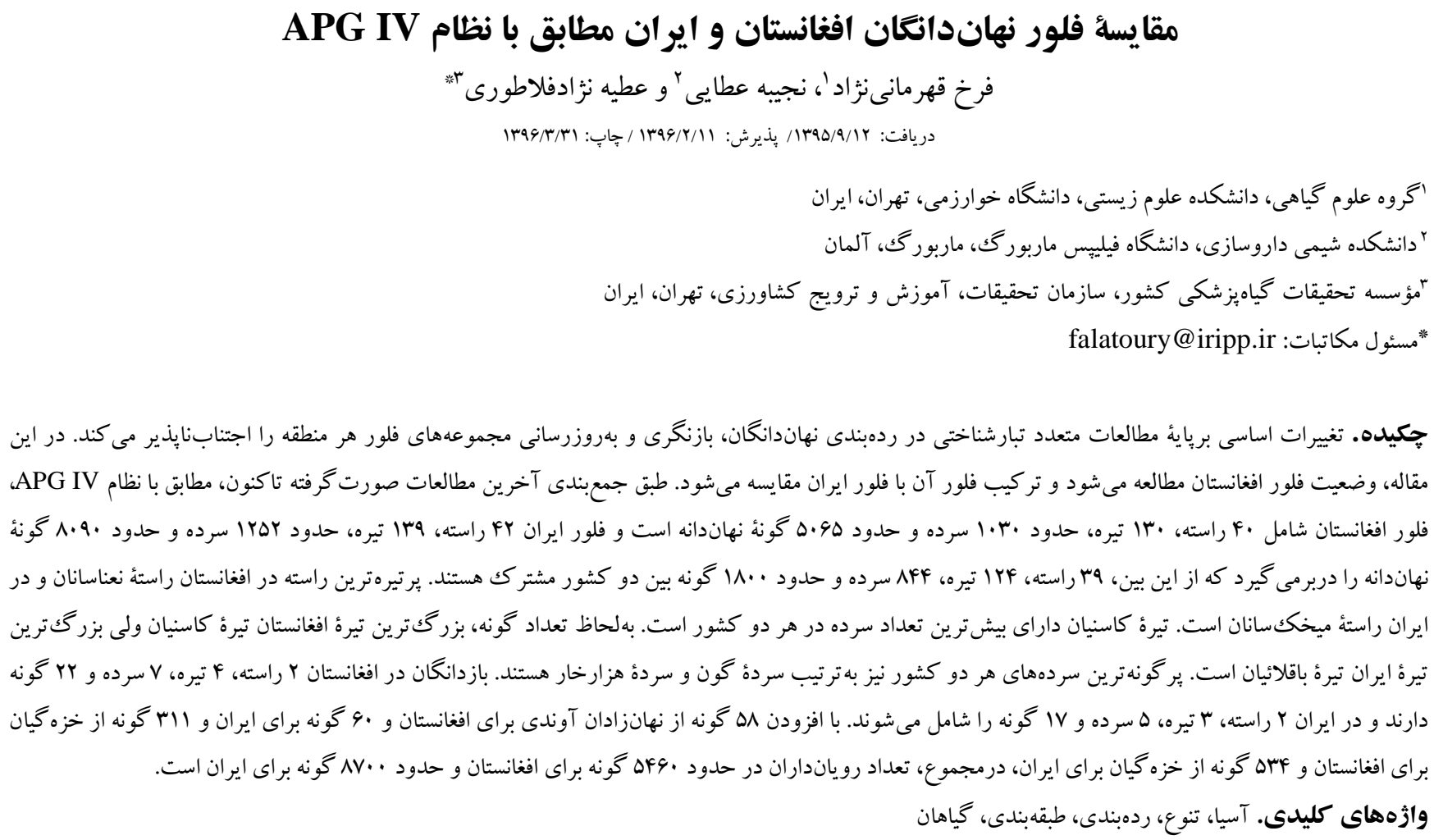

\title{
Comparison of angiosperm flora of Afghanistan and Iran in accordance with APG IV system
}

\author{
Farrokh Ghahremaninejad ${ }^{1}$, Najibeh Ataei $^{2}$ \& Atiye Nejad Falatoury ${ }^{3 *}$ \\ Received 02.12.2016/ Accepted 01.04.2017/ Published 21.06.2017
}

${ }^{1}$ Department of Plant Sciences, Faculty of Biological Sciences, Kharazmi University, Tehran, Iran

${ }^{2}$ Institut für Pharmazeutische Chemie - Philipps-Universität Marburg, Marburg, Germany

${ }^{3}$ Iranian Research Institute of Plant Protection, Agricultural Research, Education and Extension Organization (AREEO), Tehran, Iran

"Correspondent author: falatoury@iripp.ir

\begin{abstract}
Considering fundamental changes in the classification of angiosperms, based on phylogenetic studies, makes revising and updating Floras inevitable. Hence, in this paper, changes in the flora of Afghanistan have been listed and compared with the flora of Iran. As the latest studies indicate, according to APG IV system, the flora of Afghanistan comprises 40 orders, 130 families, about 1030 genera and 5065 species of angiosperms. In comparison the flora of Iran comprises 42 orders, 139 families, nearly 1252 genera and 8090 species of angiosperms. Moreover, the two countries share 39 orders, 124 families, 844 genera and about 1800 species. In Afghanistan the largest number of families belongs to Lamiales and in Iran to Caryophyllales. Asteraceae contains the largest number of genera in both countries. As far as the number of species in concerned, the largest angiosperms family in Afghanistan is Asteraceae, but in Iran it is Fabaceae. The most diverse genera of both countries are Astragalus and Cousinia respectively. Gymnosperms have two orders, four families, seven genera and 22 species in Afghanistan, while in Iran they have two orders, three families, five genera and 17 species. By adding 58 species of pteridophytes and 311 species of bryophytes to Afghanistan's flora and 60 species of pteridophytes and 534 species of bryophytes to Iran's flora, in total, Embryophyta have approximately 5460 species in Afghanistan and 8700 species in Iran.
\end{abstract}

Keywords. Asia, classification, diversity, plants, taxonomy 
2016; IPNI, 2017 مقايسه شده است. از آنجاكه بهطور ييوسته كونهاى جديدى براى فلور دو كشور معرفى يا گزارش مىشوند Akhani, \& Ghorbani, 2003; Rahiminejad et al., 2004; ) Fadaie et al. 2006; Sajedi \& Amini, 2006; Zare et al., 2007; Zaeifi \& Ramazanzade, 2009; Pahlevani \& Sajedi, 2011; Mozaffarian, \& Yaghoubi, 2015; (Mirtadzadini et al., 2016; Mozaffarian, 2016 محققين مختلف، نظرات متفاوتى در باب تعداد گونههاى سردهها (از قبيل متر ادفها) ارائه كردهاند (e.g. Akhani et al., 2007)، تعداد كو نهاى ذكرشده در اين مقاله تقريبى است.

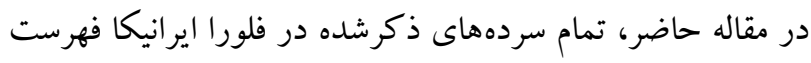
شدهاند؛ مكر اينكه كلئ كونهاى آن سرده در مطالعات بعد از از انتشار

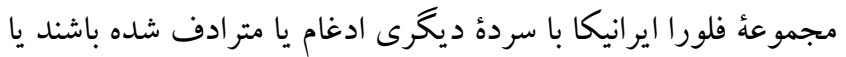
حضور آن سرده در انتشارات بعدى رد شده باشد. سردهايى كه كونههايى با عنوان "Unressolved" در "The Plant List" دارند نيز در فهرست آمدهاند. اخر گونههايى از مجموعه فلورا ايرانيكا به سردهاى جديدى كه در اين مجموعه ذكر نشدهاند، در مطالعات جديدتر منتقل شده باشند، سردههاى جديد نيز تا حد امكان در فهرست ذكر شدهاند. كفتنى است كه تلاش شده اين فهرست شامل

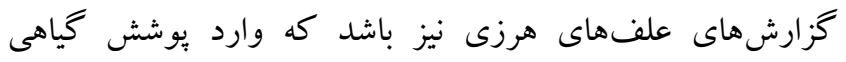

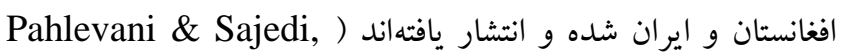
2011; Sajedi et al., 2011; Dinarvnd, \& Ale-Bakhit, - 2013; Sajedi \& Amini Rad, 2014 هايى كه براساس نظام APG در هم ادغام شدهاند، فقط به تيرههايى كه نمايندهايى در افغانستان و ايران دارند اشاره شدهاست. براى لراى

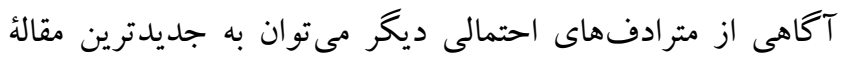

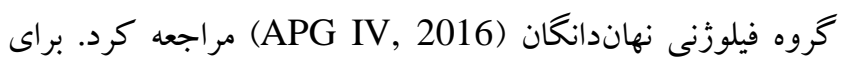
نامهاى فارسى، جز در موارد استثنايى، از مصوبات فرهنگستان زبان و ادب فارسى جمهورى اسلامى ايران ( Terminology (Departmant, 2003-2015) استفاده شده است (ضميمة )). تعلق إنى APG IV سردها به تيرهها و تيرهها به راستهها مطابق ردهبندى مشخص شدهاست. درصد شباهت بين آرايهاى دو كشور كه در متن، جدول ا و ضميمٔ r T آمده، براساس ضريب شباهت زاكارد (Jaccard similarity coefficient)

\section{مقلمهه}

افغانستان كشورى غنى ازنظر منابع و خشماندازهاى طبيعى و اغلب

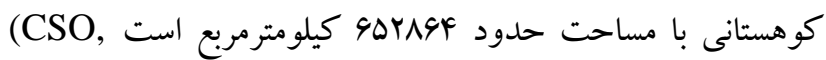

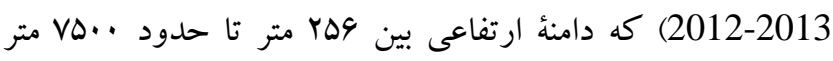
دارد. تنوع بومشناختى در مناطق مختلف، ازجمله سلسله كوههاى

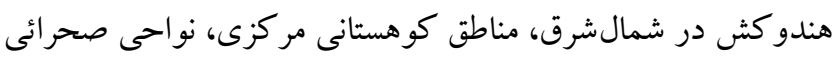
جنوبغرب و جلكههاى وسيع، فلور اين كشور را جه ازنظر تنوع

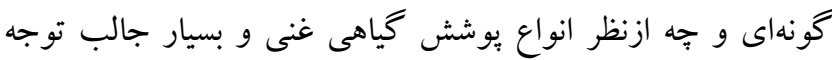

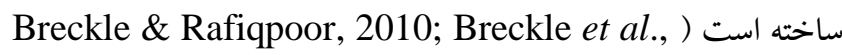
2013). نظام APG IV، تازهترين نسخهُ طبقهبندى نهاندانگان، كه

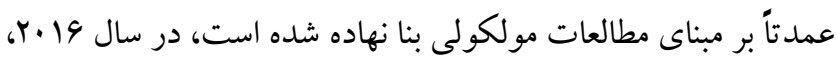

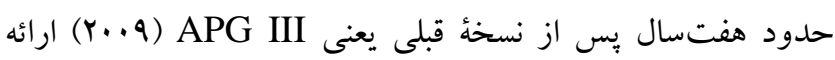
شده است. دو نسخة قديمىتر اين طبقهبندى، در سالهاى 1991 و r.. r. r منتشر شدهاند. در حال حاضر، نظام APG مطلوبترين و مقبولترين نظام ردهبندى گياهان نهاندانه ازنظر اغلب محققان گياهشناس است. ازاينرو مقاله حاضر بر آن است تا فهرستى جامع از راستهها، تيرهها و سرده -

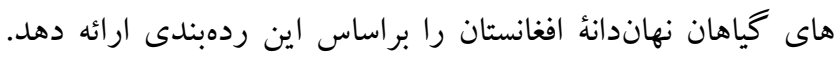
علاوهبراين، نظر به همجوارى و تشابه نسبى اقليم دو كشور افغانستان

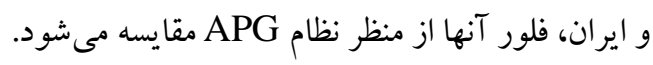

\section{مواد و روشها}

در اين نوشتار فهرست كاملى از سردهها، تيرهها و راستهایى فلور

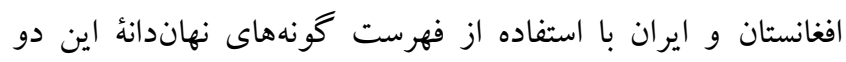

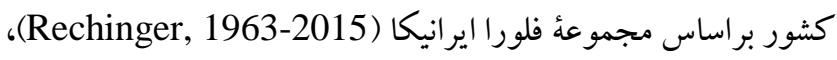
مجموعهُ فلور ايران (Assadi et al., 1989-2016)، كتاب گياهان

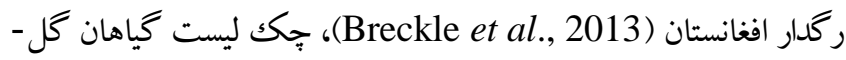
دار افغانستان (Podlech, 2012)، فهرست كامل گونههاى گياهى (B) افغانستان (Schloeder \& Jacobs, 2010)، فلور بِاكستان IPNI, ) و فهرست بين المللى نامهاى گياهى (eFlora, 2017) 2017) تهيه شدهاست. بهعلاوه، فلور افغانستان با آخرين اطلاعات

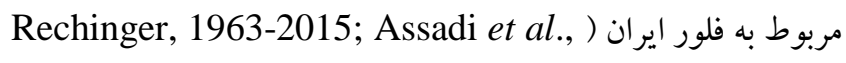
1989-2016; Ghahremaninejad \& Nejad Falatoury, 


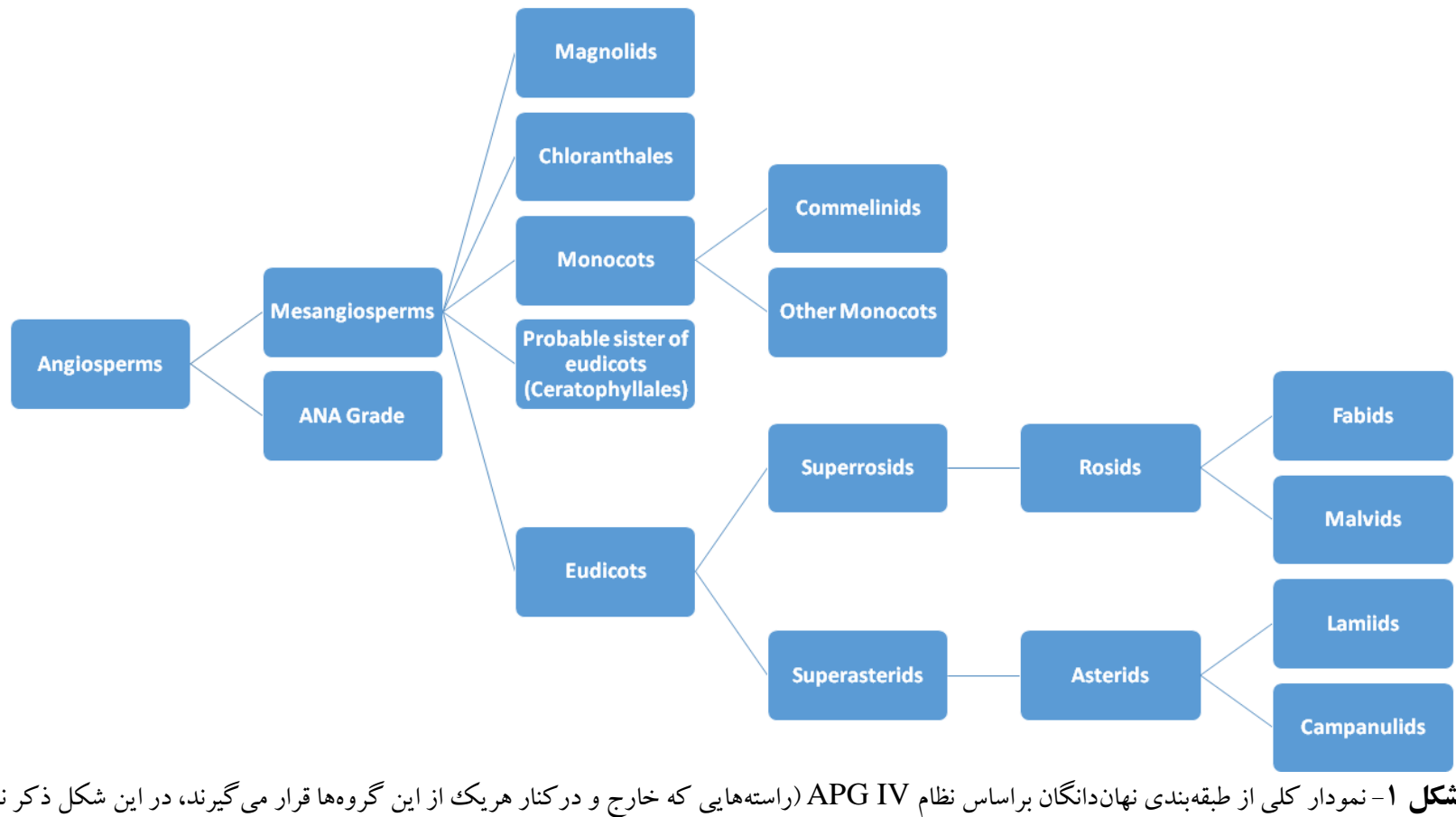

Fig. 1. An outline of APG IV system of angiosprrms' classification (outside and beside orders of neither group is not mentioned in this figure).

مزانزيوسبرمها شامل ه كلاد ما گنوليدها (Magnolids)، كُرُ انتالها (Chloranthales Mart.)

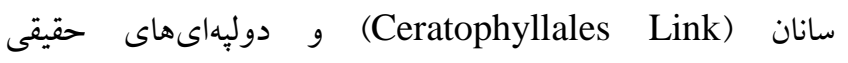
هستند. همئ خروههاى ذكرشده، به جز كُُرانتالها، نمايندههايى در محدودهُ فلورا ايرانيكا دارند.

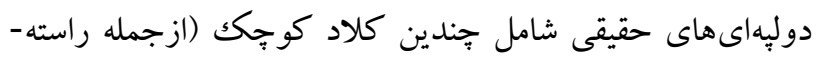

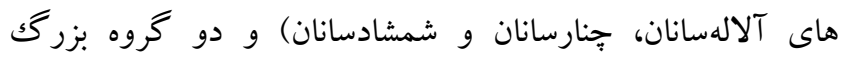
سويرززيدها (Superrosids) و سوير آستريدها (Superasterids)

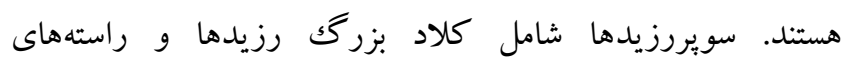
خاراشكنسانان و انكورسانان هستند. كلاد رزيدها شامل دو زير كلاد

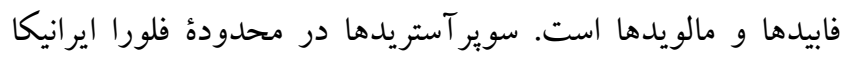
شامل كلاد بزرگك آستريدها و دو راستة صندلسانان و و راسته ميخككسانان هستند. آستريدها داراى دو زير كلاد به نامهاى لاميدها

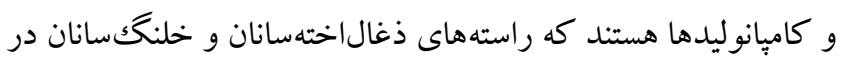
كنار اين دو كلاد بزرگك قرار مى گيرند (شكل ()). رتبة آنا (ANA Grade)
راستهها و تيرههاى موجود در افغانستان و ايران، در مجموع، شامل

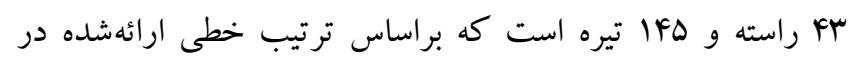

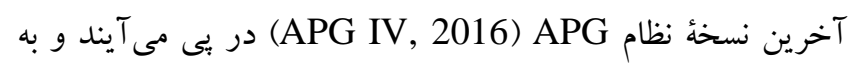
تفصيل با ذكر سردههاى هر تيره بهتفكيك در هر كشور در ضميمة أنسا

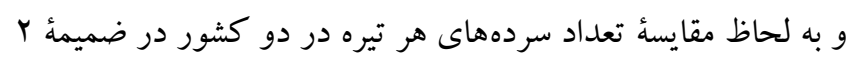

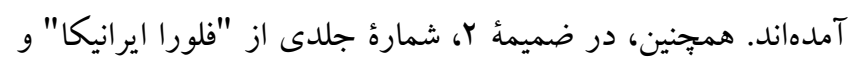

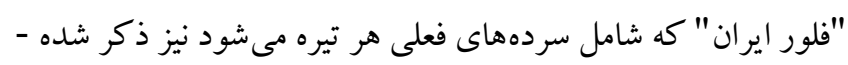

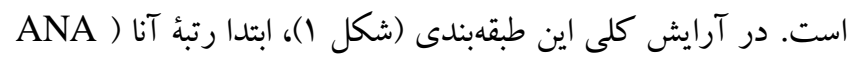

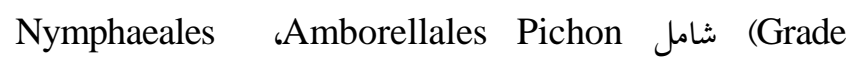
Austrobaileyales Takht. و Salisb. ex Bercht. \& J.Presl ex Reveal جدا مىشود. از اين رتبه، در محدودة (Mesangiosperms)

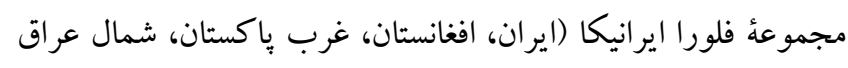
بخشهاى كوهستانى تر كمنستان و بخش كوجكى ازئ از آذربايجان

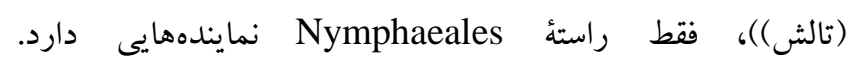


ץ (Potamogetonaceae Bercht. \& J.Presl) سرده و در ايران F سرده (Y سرده مشترك ) دارد كه Y سرده اين تيره

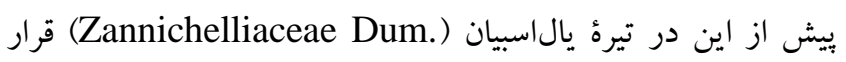

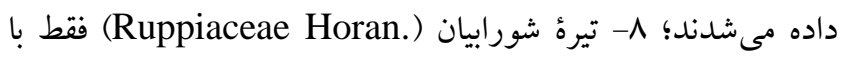
يكك سرده در ايران يافت مىشود و در افغانستان نمايندهاى ندارد؛ 9 هـ تيره سيمودوسئاسه (Cymodoceaceae Vines) كه در افغانستان عضوى ندارد و با Y سرده در ايران براكنده است كه هردو بيش از اين، متعلق به تيره يالاسبيان بودهاند.

0- راستةُ تميس إنان (Dioscoreales Mart. اين راسته با يك تيره به نام تميسيان (Dioscoreaceae R.Br.)،

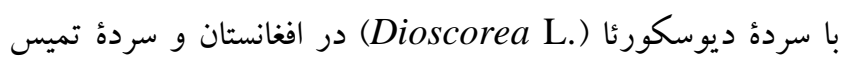
(Tamus L.) 7- راستهُ سوسنسانان (Liliales Perleb)

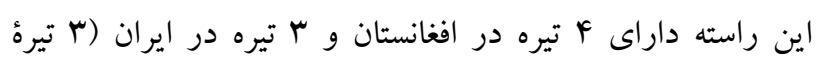

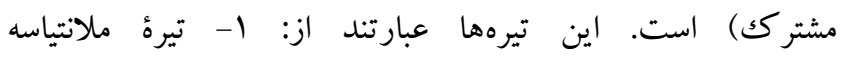
(Melanthiaceae Batsch ex Borkh.)

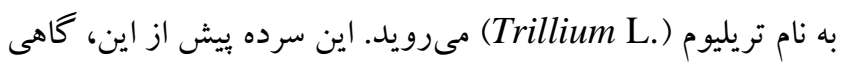
متعلق به تيره سوسنيان (Liliaceae Juss) و كاهى متعلق به تيره

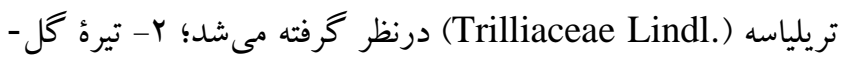

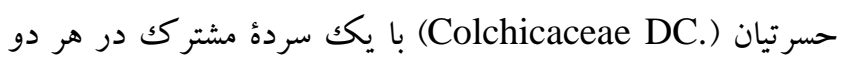

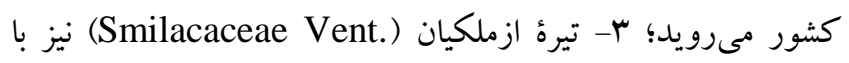
يكك سرده مشترك در هر دو كشور يافت مىشودكه اعضاى هر دو

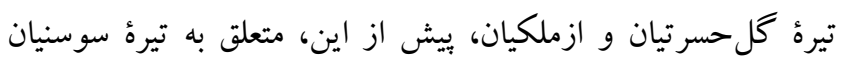

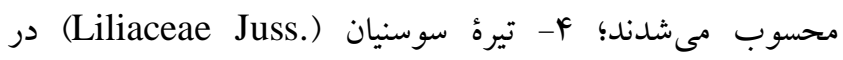
افغانستان و اير ان با V سرده (9 سردة مشتر كك) بر اكنده است.

Y- راستة مارجوبهسانان (Asparagales Link)

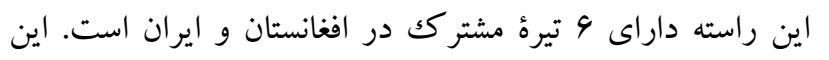

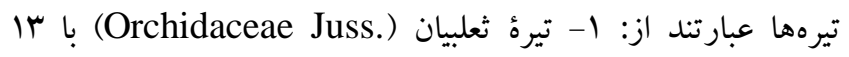
سرده در افغانستان و IV سرده در ايران (IV سرده مشترك) يافت

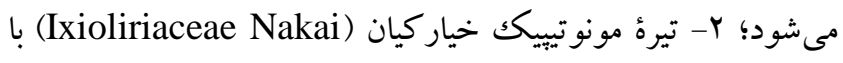
يكك سرده كه از تيره نر گسيان (Amaryllidaceae J.St.-Hil.)

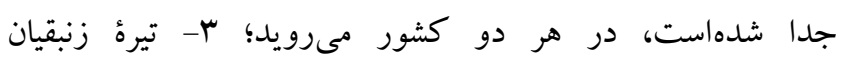

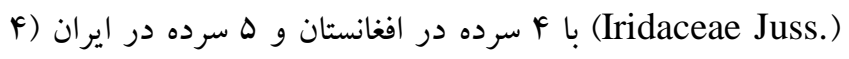

1- راستة نيلوفر آبىسانان ( Nymphaeales Salisb. ex (Bercht. \& J.Presl اين راسته با يكك تيره به نام نيلوفر آبيان ( Nymphaeaceae (Salisb. ايران حضور دارد.

\section{مز انزيوسير مها (Mesangiosperms)}

ماكنوليدها (Magnolids)

r- راستهُ فلفلسياهانان (Piperales Bercht. \& J.Presl) اين راسته در افغانستان عضوى ندارد و فقط با تيرهُ زرآونديان (ران إنان

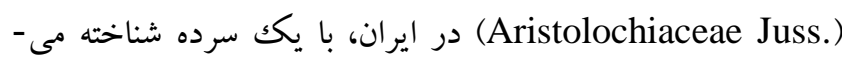
شود.

\section{تك لֶهاىها (Monocots)} r- راستة بر كىشمشيرىسانان (Acorales Mart.

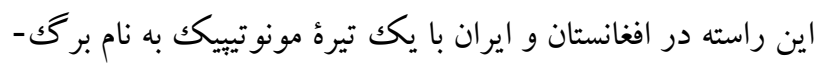

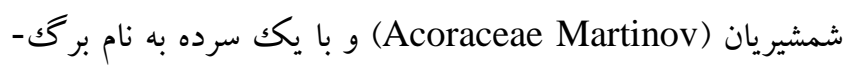

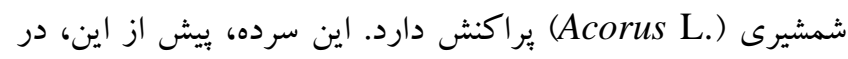
تيرهُ شييوريان (Araceae Juss) قرار مى خرفت.

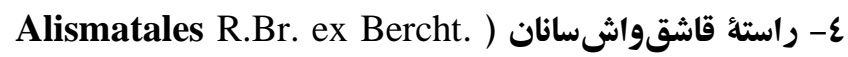
(\& J.Presl اين راسته داراى 9 تيره در افغانستان و 9 تيره در ايران (4 تيرة Araceae ( مشتركs) است. اين تيرهها عبارتند از: ا- تيره شييوريان

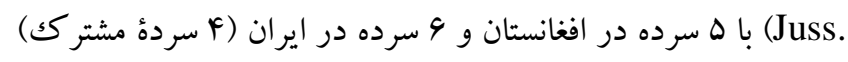

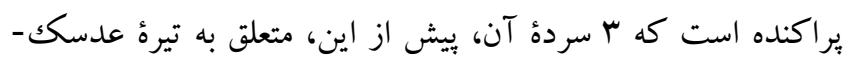

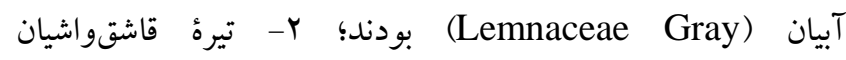
در افغانستان r سرده و در ايران r سرده بره (Alismataceae Vent.)

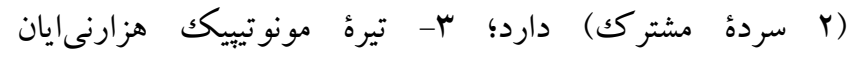
(Butomaceae Mirb.) F- تيرءٔ تختقورباغهايان (Hydrocharitaceae Juss)، كه تيرة تيز كيان (Najadaceae Juss) در آن ادغام شده است، در افغانستان r سرده و در ايران 9 سرده (r سردهُ مشتركs) دارد؛ ه- تيره سه-

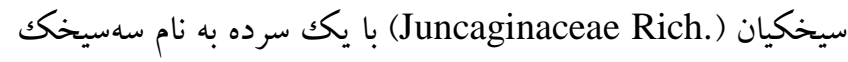
(Triglochin L.) (Zosteraceae Dumort.)

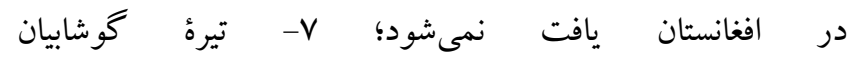


رويد؛ ه- تيرء گندميان (Poaceae Barnhart) ازنظر تعداد سرده با حدود 119 سرده در افغانستان و ·با سرده در ايران (9V سردهٔ مشترك) دومين تيرهٔ مهم هر دو كشور محسوب مىشود و ازنظر

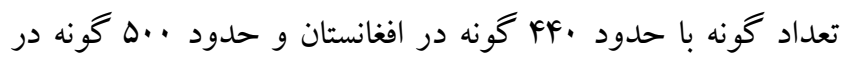
ايران، سومين تيرهُ ير گونهُ هر دو كشور بهشمار مى آيد.

خواهر احتمالى دوليهاى إهاى حقيقى ( Probable sister of (Eudicots

11 - راستة بركىشاخسانان (Ceratophyllales Link)

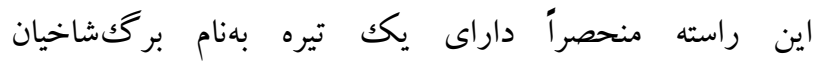
و و يك سرده به نام بركُشاخى (Ceratophyllaceae Gray) است كه در هر دو كشور مىرويد.

\section{دولٍهاىهاى حقيقى (Eudicots)}

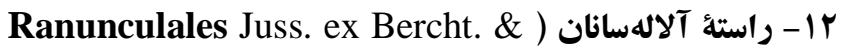

(J.Presl

اين راسته داراى ץ تيره در افغانستان و ץ تيره در ايران (ץ تيرهٔ

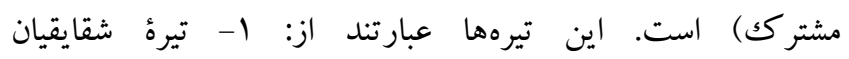
(Papaveraceae Juss.)

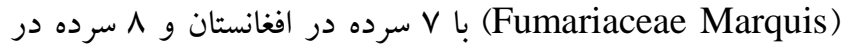

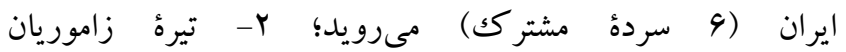
با يكك سرده، فقط در ايران يافت مى (Menispermaceae Juss.)

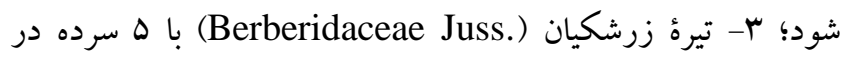

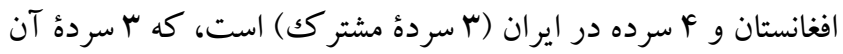
بيش از اين در تيرهٔ يودوفيلاسه (Podophyllaceae DC) جاى

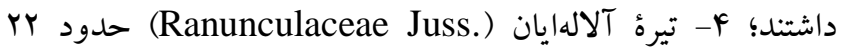
سرده در افغانستان و اب سرده در ايران ( •r سرده مشتركك) دارد.

Proteales Juss. ex Bercht. \& ) براس (J.Presl اين راسته داراى يكك تيره در افغانستان و r تيره در ايران (يكك تيره

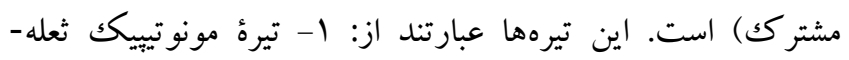
باقلائيان (Nelumbonaceae A.Rich.) كه با يكك سرده فقط در ئر ايران وجود دارد، سرده .Nelumbo Adans ييش از اين، از اعضاى

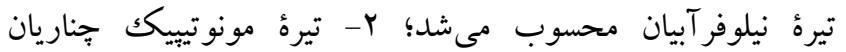

Platamus) كه با يك گونه جنار (Platanaceae T. Lestib.)
سردة مشتر كs) ير اكنش دارد؛ f- تيرهٔ سريشيان ( Asphodelaceae (Juss.

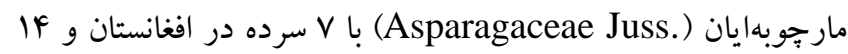
سرده در ايران (9 سرده مشتركك) بِراكندهاست كه همه، ييش از اين، متعلق به تيرهٔ سوسنيان در مفهوم وسيع بودهاند يا بعضى از سردهها كاهى در تيرهُ سنبليان (Hyacinthaceae Batsch ex Borkh.) Amaryllidaceae J.St.-) قرار داده مى شدند؛ 9- تيرهُ نر گسيان (Hil. مشتركs) است كه محدودة تيره ييازيان (Alliaceae Borkh) و

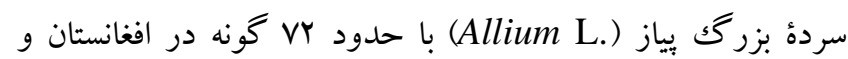
حدود سبا گونه در ايران را شامل مىشود.

كاملينيدها (Commelinids) 1-1 راستة نخلسانان (Arecales Bromhead) Arecaceae Bercht. \& ) اين راسته با يك تيره به نام نخليان

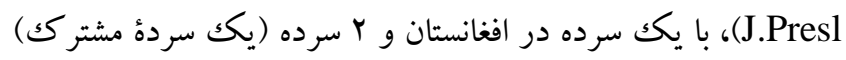
در ايران براكنده است.

ج- راستة بركبيدىسانان ( Commelinales Mirb. ex (Bercht. \& J.Presl اين راسته با Y تيره در افغانستان و يكك تيره در ايران (يكك تيره

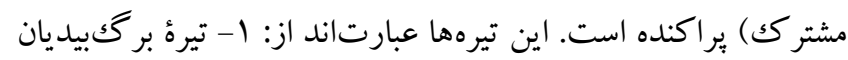

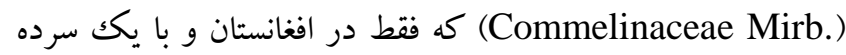
مىرويد؛ r- تيرهُ غلافيان (Pontederiaceae Kunth)، كه با يكك سرده در افغانستان و r سرده در ايران (يك سرده مشترك) يافت مىشود.

• 1 - راستة كندمسانان (Poales Small)

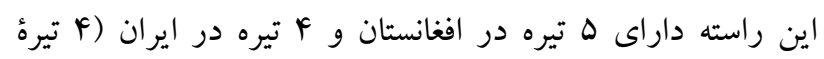

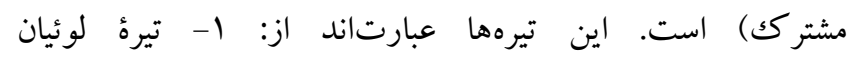
كه با r سرده مشترك در هر دو كشور (Typhaceae Juss.) حضور دارد؛ r- تيرهٔ اريو كولاسه (Eriocaulaceae Martinov) فقط با يك سرده در افغانستان يافت مىشود؛ بـ تيره جكنيان (Cyperaceae Juss.) در ايران (10 سرده مشتركs) يُراكنش دارد؛ \&- تيرة سازوئيان

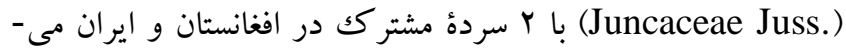


تيرءٔ باقلائيان با حدود •90 گونه در افغانستان ازنظر تعداد گونه

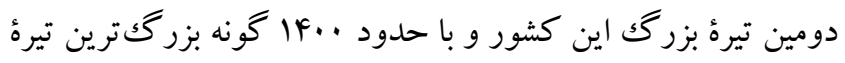

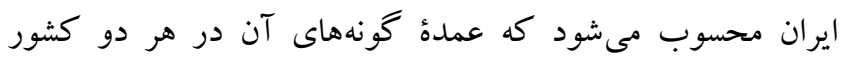

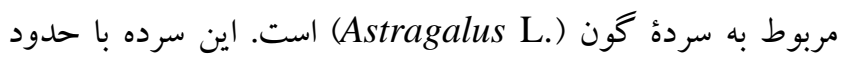
.

Gharemaninejad, 2015; Maassoumi, 2015; Bidarlord ) et al., 2016; Ghahremaninejad et al., 2016; Bagheri et (al., 2017 شود كه يراكنش و تنوع جشمخيرى در محدودهُ فلورا ايرانيكا دارد.

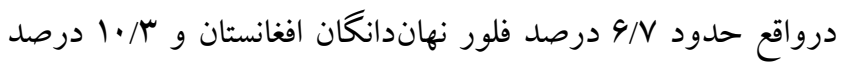
آن در ايران مربوط به سرده گون است؛ ب- تيره شيرآوريان با يكك سردة مشترك (Polygalaceae Hoffmanns. \& Link)

$$
\text { در افغانستان و ايران براكنده است. }
$$

19 - راستة كل مرخخ انانان (Rosales Bercht. \& J.Presl)

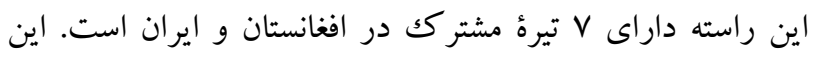

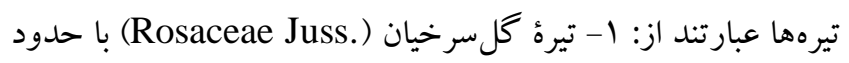

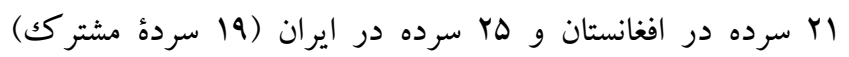
ير اكنده است. شايان ذكر است درنتيجهُ مطالعات تبارشناختى سردههاى بادام (Amygdalus L.)، زردآلو (Armeniaca Scop.)، آلبالو (Cerasus Mill.)، ديو آلبالو ( Lauro-cerasus

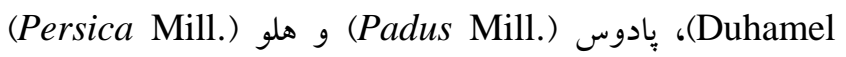
مترادف سردة آلو (Prunus L.) بهشمار مى آيند و در اينجا نيز بر همين اساس بهصورت يكك سرده در نظر گرفته شدهاند؛ ب- تيره سنجديان (Elaeagnaceae Juss.) r سردة مشتركs در هر دو كشور دارد؛ س- تيرهٔ عنابيان (Rhamnaceae Juss) با هـ سرده در هر كشور (F سرده مشترك) يافت مىشود؛ F- F- تيره نارونيان با يكك سرده در افغانستان و Y سرده در ايران (Ulmaceae Mirb.) (يكك سردة مشترك) ديده مىشود؛ ه- تيرء شاهدانهايان r) r سرده در افغانستان و r سرده (Cannabaceae Martinov) سرده مشترك) در ايران دارد؛ گفتنى است كه سرده داغداغان براساس مطالعات مولكولى از تيره نارونيان به تيره Moraceae ) شاهدانهايان منتقل شده است؛ 9- تيره توتيان (Gaudich. (orientalis L.

عا- راستهُ شمشادسانان (Buxales Takht. ex Reveal) اين راسته داراى يكك تيره به نام شمشاديان ( Buxaceae (Dumort.

سويرزيدها (Superrosids)

Saxifragales Bercht. \& J. ) راسته خاراشكنسانان (Presl اين راسته داراى V تيرهٔ مشترك در افغانستان و ايران است. اين تيرهها عبارتند ازئ با يكك سرده مشترك، كه بيش از اين، در (Paeoniaceae Raf.)

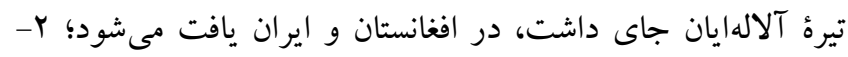

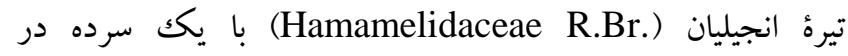

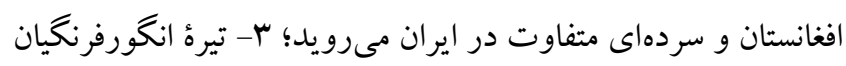
(Grossulariaceae DC.)

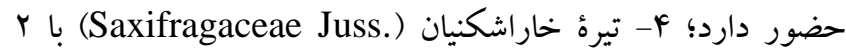
سرده در افغانستان و يكك سرده در ايران (يكك سرده مشترك)

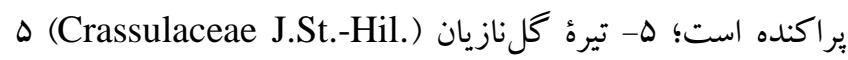
سرده در افغانستان و 9 سرده در ايران (r سردة مشترك) دارد؛ 9-

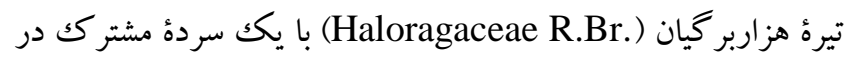

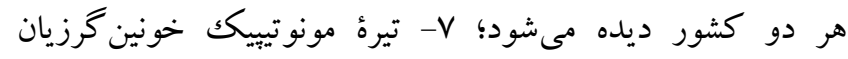
با يكك سردة مشترك در (Cynomoriaceae Endl. ex Lindl.)

$$
\text { افغانستان و ايران ير اكنش دارد. }
$$

رزيدها (Rosids)

17 - راستة انغورسانان (Vitales Juss. ex Bercht. \& J.Presl)

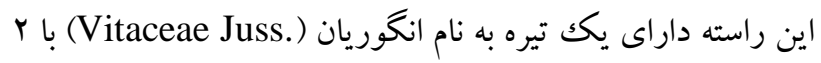
سرده مشترك در افغانستان و ايران است.

فابيدها (Fabids)

إستهُ قيجسانان (Zygophyllales Link) اين راسته با تيرهُ قيجيان (Zygophyllaceae R.Br.) با F أن سرده مشتر كك در افغانستان و ايران يراكنده است.

11 - راستهُ باقلاسانان (Fabales Bromhead)

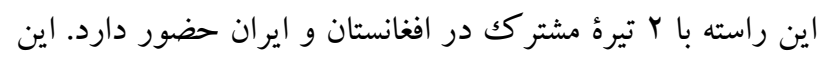

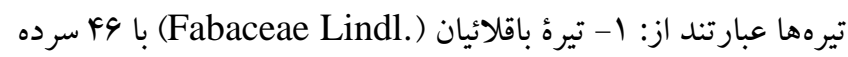
در افغانستان و 90 سرده در ايران (Fr سرده مشتر ك) يراكنده است. 


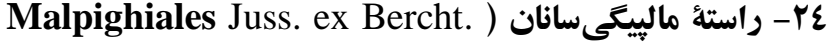
(\& J.Presl اين راسته داراى Vيره در افغانستان و ^ تيره در ايران V) تيرهٔ مشترك) است. كه اين تيرهها عبارتند از: ا- تيره: جندليان

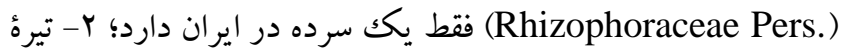
گلراعيان (Hypericaceae Juss) يكك سردهُ مشتر كك در هر دو يران

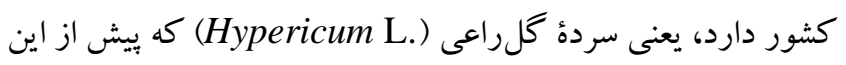

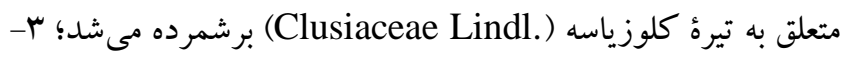
تيرة الاتيناسه (Elatinaceae Dumort.) با يكك سرده در افغانستان و Y سرده در ايران (يكك سرده مشتر كs) يراكنش دارد؛ F ايان (Violaceae Batsch) با يكك سرده مشتر كى در هر دو كشور حضور دارد؛ ه- تيره بيديان (Salicaceae Mirb.) با ب سردهٔ مشترك در هر دو كشور يافت مىشود؛ 9- تيره فرفيونيان (Euphorbiaceae Juss.) ايران (r سرده مشتركك) مىرويد؛ V- تيره كتانيان ( Linaceae DC - با يكك سرده مشترك در افغانستان و ايران ديده مى (ex Perleb

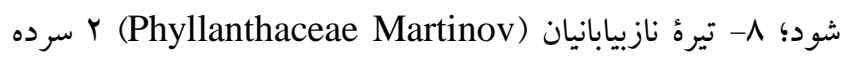

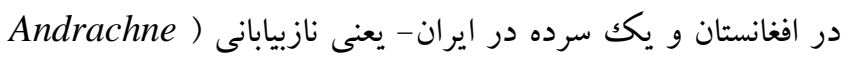
(L.

مالويدها (Malvids)

Oraniales Juss. ex Bercht. \& ) راستة شمعدانىسانان (J.Presl Geraniaceae ) اين راسته داراى يكك تيره به نام شمعدانيان (Juss. ايران (r سرده مشترك ) دارد.

Myrtales Juss. ex Bercht. \& ) جr- راستهُ موردسانان (J.Presl اين راسته داراى ץ تيرهٔ مشترك در افغانستان و ايران است. اين F تيرهها عبارتند از: إئ تيره حنائيان (Lythraceae J.St.-Hil.)

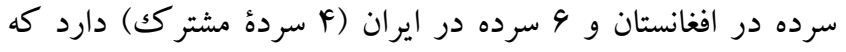
براساس مطالعات تبارشناختى Y تيره اناريان ( Punicaceae (Horan.

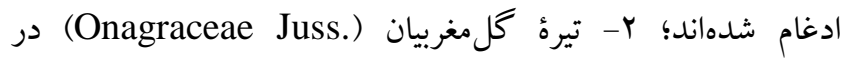

مشتر كك) ير اكنده است؛ V- تيره: گز نهايان (Urticaceae Juss) با هـ

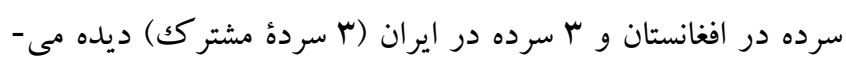
شود.

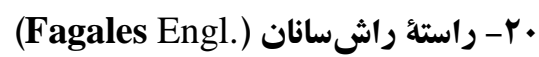
اين راسته داراى ب تيرهُ مشتر كك در افغانستان و ايران است. اين تيرهها عبارتند از: ا- تيره راشيان (Fagaceae Dumort.) با يكك ديك

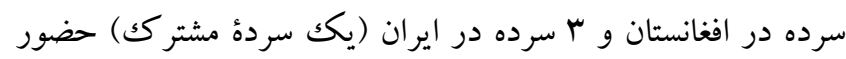
دارد؛ r- تيرة گردوئيان (Juglandaceae DC. ex Perleb) با يكك

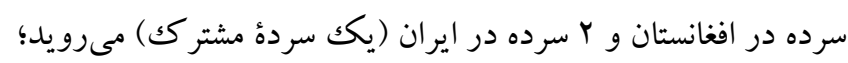

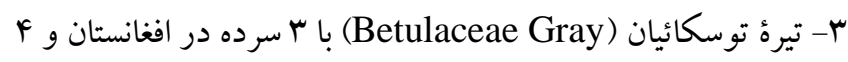
سرده در ايران (سه سرده مشترك) بر براكنده است. سردههاى ممرز (Carpinus L.)

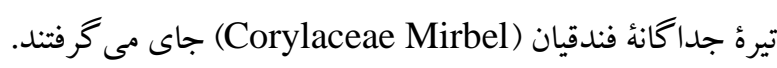
ابr راستة كدوسانان ) \&ucurbitales Juss. ex Bercht. \& (J.Presl اين راسته داراى Y تيره در افغانستان و ץ تيره در ايران (Y تيرهٔ مشترك) است. اين تيرهها عبارتند از: ا- تيره خونفاميان فقط داراى يك سرده در (Apodanthaceae Tiegh. ex Takht.) Rafflesiaceae ) ايران است كه ييش از اين در تيرهُ رافلزيائيان

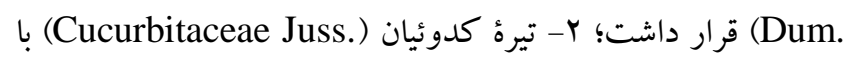

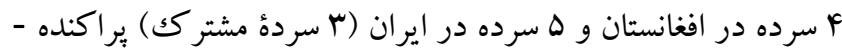

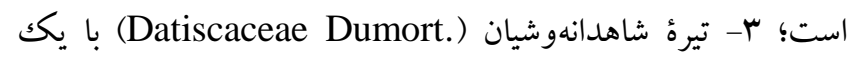
سرده مشتر كك در هر دو كشور حضور دارد.

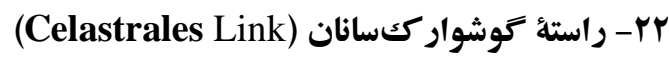
اين راسته داراى يكك تيرهُ مشترك در افغانستان و ايران است. تيره

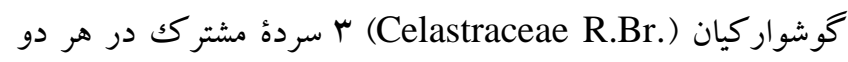

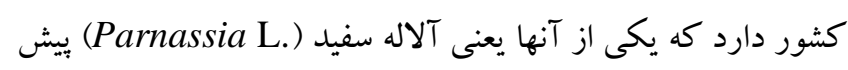

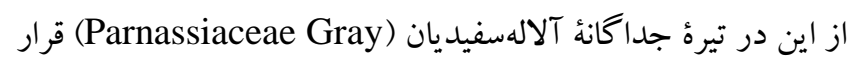
مى كرفت.

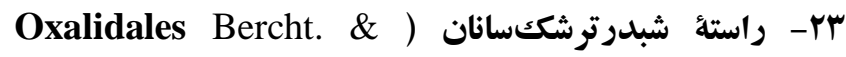
(J.Presl

اين راسته داراى يكك تيره به نام شبدرترشكيان ( Oxalidaceae و و يك سردة مشتر كك در افغانستان و ايران است. R.Br. 
داراى يك سرده مشترك در افغانستان (Neuradaceae Kostel.) و ايران است كه بيش از اين در تيرة كل سرخيان (Rosaceae) قرار

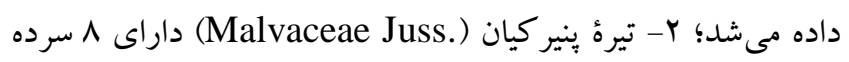
در افغانستان و له سرده در ايران (N سرده مشتركك) است كه تيره

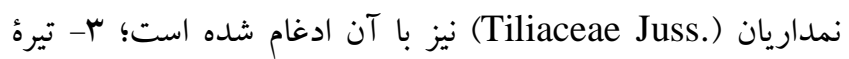
مازريونيان (Thymelaeaceae Juss. با 9 سرده در افغانستان و ه ه سرده در ايران (ه سرده مشتر ك) حضور دارد؛ F- تيره كل آفتابيان (Cistaceae Juss.)

$$
\text { سرده در ايران ديده مىشود. }
$$

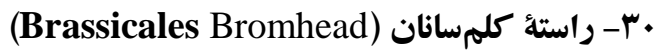

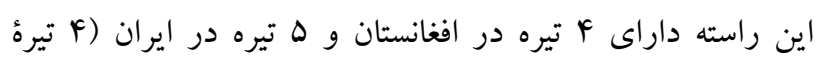

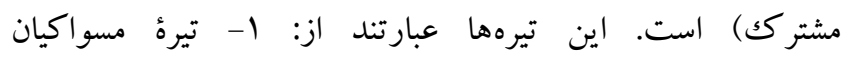
- كه با يكك سرده فقط در ايران يافت (Salvadoraceae Lindl.) مىشود و در افغانستان نمايندهاى ندارد؛ ب- تيره اسبركيان يك سرده در افغانستان و r سرده در (Resedaceae Martinov) ايران (يكك سرده مشترك) دارد؛ ب- تيرهُ كبريان ( Capparaceae (Juss.

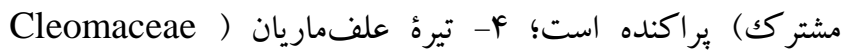
(Bercht. \& J.Presl (يكك سرده مشترك) حضور دارد كه بيش از اين متعلق به كبريان

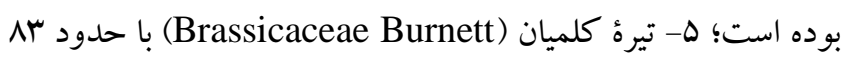
سرده در افغانستان و \ه سرده در ايران (19 سردهُ مشتركك) مىرويد. تيره كلميان ازنظر تعداد سرده در افغانستان سومين و در ايران جهارمين تيرهُ بزر گك محسوب مى شود. به علاوه به لحاظ تعداد گونه

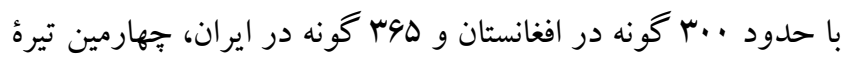

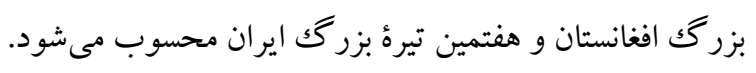

\section{سوير آستريدها (Superasterids)}

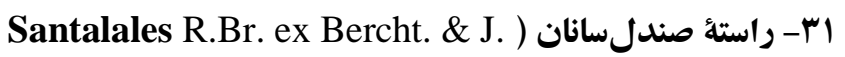

(Presl اين راسته با Y تيرهُ مشترك در هر دو كشور مىرويد. اين تيرهها

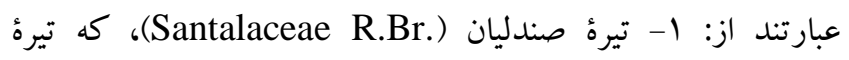
دارواشيان (Viscaceae Batsch) در آن ادغام شدهاست، با ب سرده در افغانستان و F سرده در ايران (Y سرده مشترك) مىرويد؛ Y- تيرهٔ
افغانستان و ايران با F سردة مشترك مىرويد؛ ب- تيرة مورديان

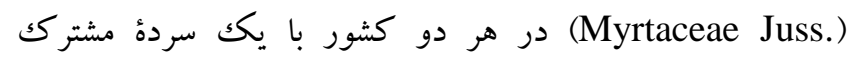
براكنش دارد.

Crossosomatales Takht. ex ) راستة كروسوسوماتال (Reveal Staphyleaceae ) اين راسته با يك تيره به نام خوشهايان

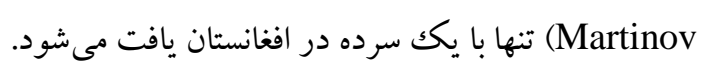

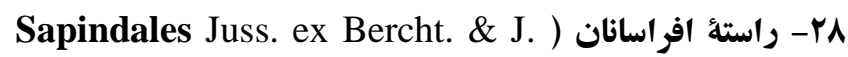
(Presl اين راسته داراى 9 تيره در افغانستان و V تيره در ايران (4 تيرهٔ مشتركs) است. اين تيرهها عبارتند از: ا- تيره مونوتيبيكك آدمكيان (Biebersteiniaceae Schnizl.)

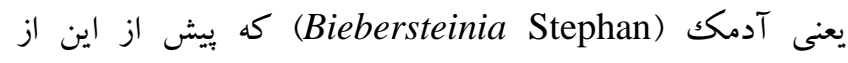
شمعدانيان برشمرده مىشد، يراكنش دارد؛ ب- تيره قرهداغيان (Nitrariaceae Lindl.)

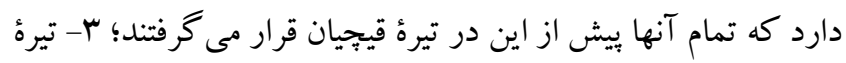

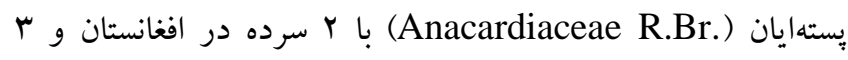
سرده در ايران (Y سرده مشترك) يافت مىشود؛ F- تيره ناتر كيان r سرده در افغانستان و r سرده در ايران (Sapindaceae Juss.) سرده مشتر ك) دارد كه محدوده جديد اين تيره شامل تيره افرائيان Rutaceae ) نيز مىشود؛ ه- تيرة سدابيان (Aceraceae Juss.)

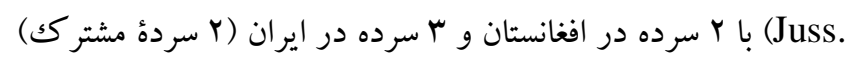

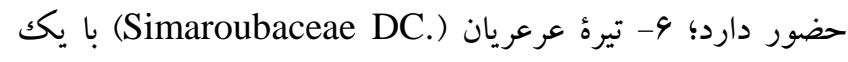
سردهُ مهاجم در هر دو كشور براكنش دارد؛ V- تيرهُ زيتونتلخيان

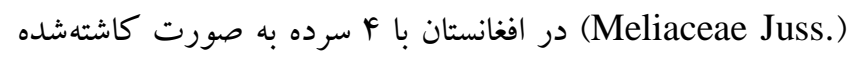
وجود دارد، كه يكى از آنها يعنى زيتون تلخ (Melia L.) بهصورت نيمه خودرو نيز گزارش شده است. اين تيره در ايران با ب سرده (يكك

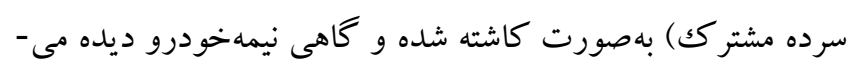
شود. Malvales Juss. ex Bercht. \& ) وب- راستة هنير كسانان (J.Pres1 اين راسته داراى ץ تيره در افغانستان و ץ تيره در ايران (ץ تيره مشترك) است. اين تيرهها عبارتند از: ا- تيره ت تكمهنيان 
تيرهٔ مونوتييكك جيسكياسه (Gisekiaceae Nakai) با يك

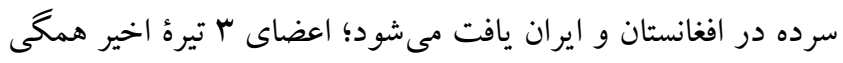

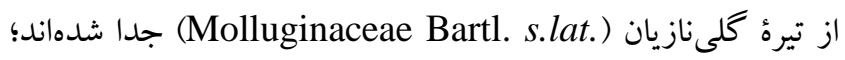

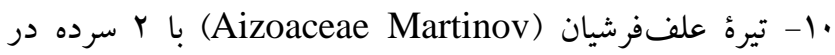
افغانستان و ه سرده در ايران (Y سردة مشتركك) ديده مىشود؛ تيره سرخابكوليان (Phytolaccaceae R.Br.) با يكك سرده مشترك در هر دو كشور مىرويد؛ با- تيره كل كاغذيان (Nyctaginaceae Juss.) ايران (يكك سردهُ مشتركى) پبراكنده است؛ سا- تيره كلى نازيان - با يكك سرده تنها در ايران يافت مي اليره (Molluginaceae Bartl.)

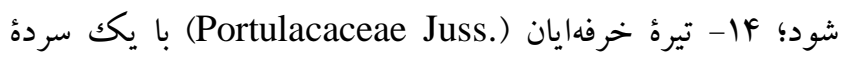
مشتر كك در هر دو كشور مىرويد.

آستريدها (Asterids)

rس- راستهُ ذغال اختهسانان (Cornales Link)

Cornaceae ) اين راسته داراى يك تيره به نام ذغالاختهائهان (C) با يكك سردهُ مشتركك در افغانستان و ايران (Bercht. \& J.Presl

ع ع- راستهُ خلنكَسانان (Ericales Bercht. \& J.Presl)

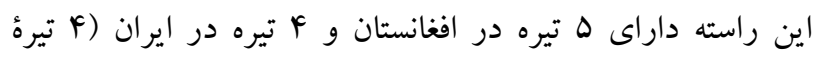

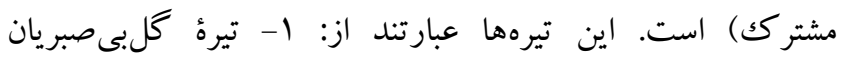

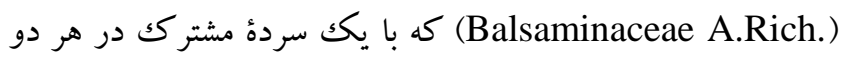
كشور حضور دارد؛ r- تيرهٔ سايوتاسه (Sapotaceae Juss) با يكك سرده، فقط در افغانستان يافت مىشود. ب- تيره خرمالوئيان يكك سرده مشترك در هر دو كشور دارد؛ (Ebenaceae Gürke) ץ- تيرهُ پامجاليان (Primulaceae Batsch ex Borkh) در هر

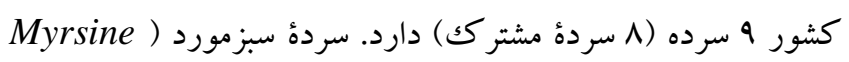

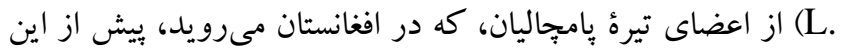
در تيرهُ سبزمورديان (Myrsinaceae R.Br.) قرار داده مىشد؛ ه-

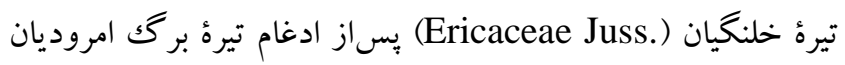
Monotropaceae ) و تيرة تككسوئيان (Pyrolaceae Dum.) (Nutt. مشتر ك) ) را شامل مىشود.

لاميدها (Lamiids)
موخوريان (Loranthaceae Juss) فقط با يكك سرده مشترك در هر دو كشور براكنده است.

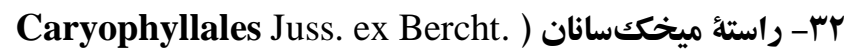

(\& J. Presl اين راسته داراى |ل تيره در افغانستان و \&| تيره در ايران (1ا تيرهٔ

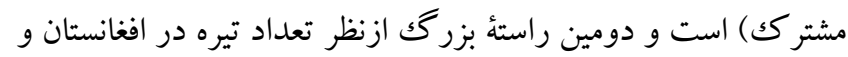

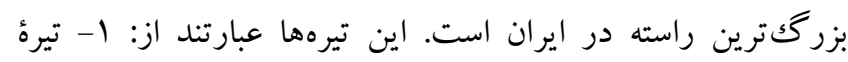

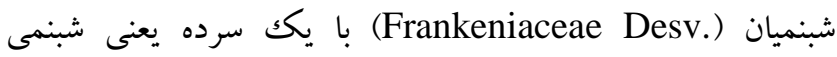
(Frankenia L.) با F سرده در افغانستان و ب سرده در ايران (Tamaricaceae Link)

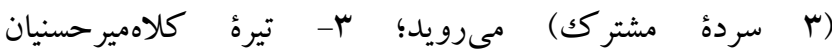
با ^ سرده در افغانستان و 9 سرده در (Plumbaginaceae Juss.) ايران (F سرده مشتركs) حضور دارد؛ F- تيره علف هفتبنديان (Polygonaceae Juss.) ايران (N سردة مشترك) ديده مىشود؛ ه- تيره ميخكيان

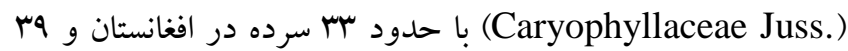
سرده در ايران (Dا سردهُ مشترك) بِراكنده است كه سردهُ سيلن يا

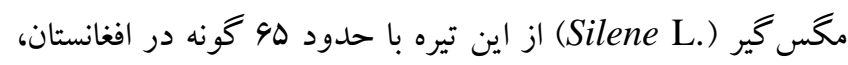

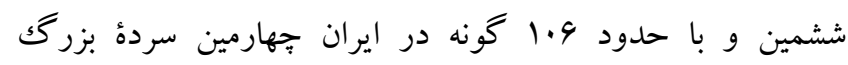

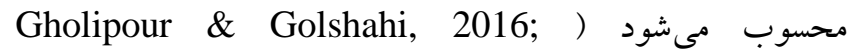
Gholipour et al., 2016; Gholipour, 2017; Hoseini et (Amaranthaceae Juss.) (al., 2016 ( 9- تيره تاجخروسيان

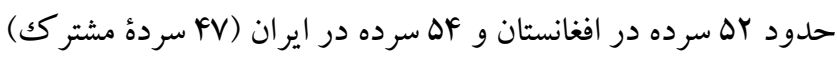
دارد كه مطالعات تبارشناختى ادغام تيره اسفناجيان (Chenopodiaceae Vent.) ذكر است در اين مقاله سرده Dysphania R.Br. براساس گزارش

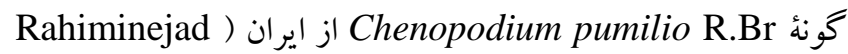
Dysphania pumilio كه نام يذيرفته شده آن (et al., 2004 The plant list, ) است (R.Br.) Mosyakin \& Clemants 2017) جزو فلور ايران ذكر شده است. V- تيره ليمهآسه با يكك سرده، فقط در (Limeaceae Shipunov ex Reveal) ايران يافت مىشود؛ \- تيره لوفيو كارياسه ( Lophiocarpaceae

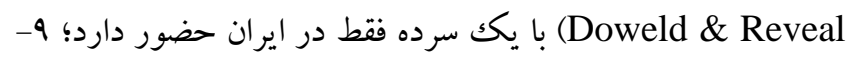


qr- راستة نعناسانان (Lamiales Bromhead)

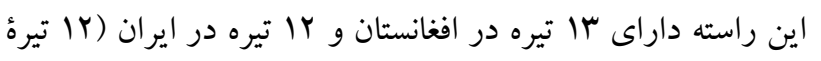

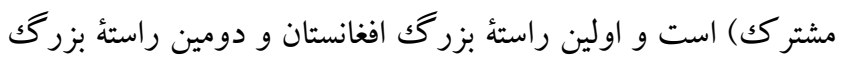
ايران ازنظر تعداد تيره محسوب مىشود. اين تيرهها عبارتند از: ا-

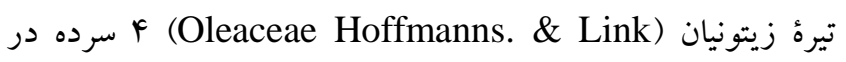

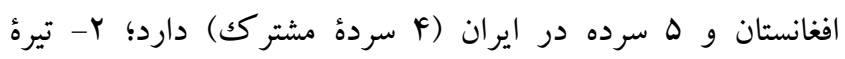

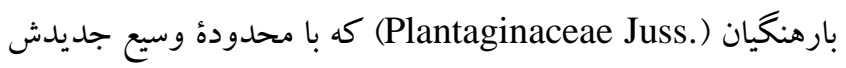

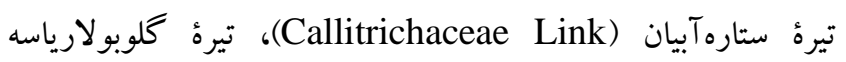
Hippuridaceae (Globulariaceae DC.) (Link. را نيز دربرمى گيرد، در افغانستان (Scrophulariaceae Juss.)

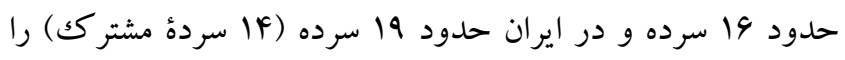
شامل مىشود؛ ץ- تيرة گل ميمونيان (Scrophulariaceae Juss) سرده در افغانستان و r سرده در ايران (r سرده مشتركs) دارد.

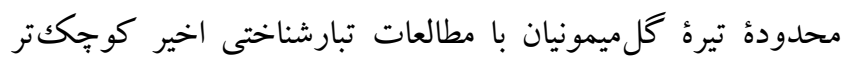
شده و تعداد زيادى از سردههايى كه سابق براين، در اين تيره جاى دئي

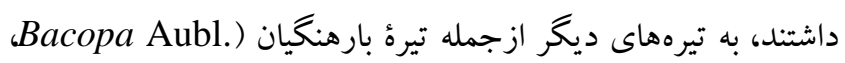
‘Gratiola L. ‘Digitalis L. ،Chaenorhinum (DC.) Rchb. ‘Limosella L. ‘Lagotis E.Mey. ‘Kickxia Dumort. „Nanorrhinum Betsche ،Misopates Raf. ‘Linaria Mill. (Veronica L. و و تيرء گل جاليزيان ،Bungea C.A.Mey.) Orobanchaceae Vent. يا ،Leptorhabdos Schrenk ،Lathraea L. ‘Euphrasia L. Melampyrum ، Lindenbergia Lehm. ex Link \& Otto Pedicularis ‘Parentucellia Viv. ،Odontites Spreng. ،L. (Rhynchocorys Griseb. و Rhinanthus L. ،L. سرده .Buddleja L، كه فقط در افغانستان مىرويد و در ايران بهصورت كاشتهشده وجود دارد و وييش از اين در تيره دمموشيان (Loganiaceae R.Br. ex Mart.) تيرة: كلميمونيان شمرده مىشود؛ (Linderniaceae Borsch, Kai Müll. \& Eb.Fisch.) سردة مشترك در هر دو كشور يافت مىشود؛ ه- تيره كنجديان

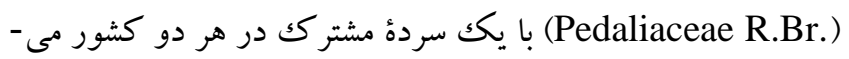

Or- راستةُ كلسياسىسانان ( Gentianales Juss. ex Bercht. (\& J. Presl اين راسته داراى ب تيرهٔ مشترك در هر دو كشور است. اين تيرهها

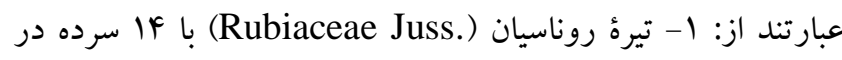

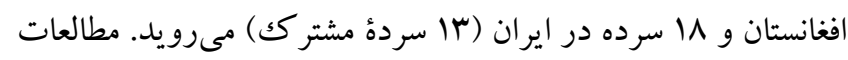

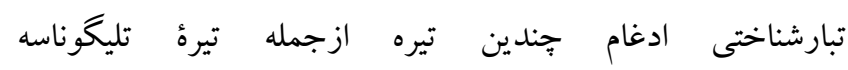
(Theligonaceae Dum.)

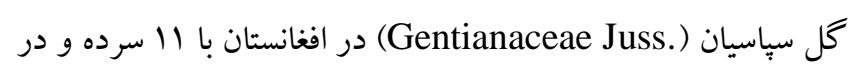
ايران با ه سرده (ه سرده مشتركs) مىرويد؛ ب- تيره خرزهرهايان كه براساس مطالعات تبارشناختى محدودة (Apocynaceae Juss.) تيرهُ استبرقيان (Asclepiadaceae R.Br.) را نيز دربرمى گيرد، در

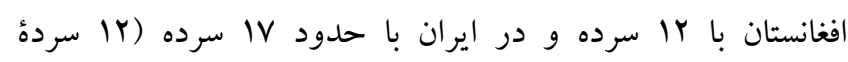
مشتر كى) ديده مىشود.

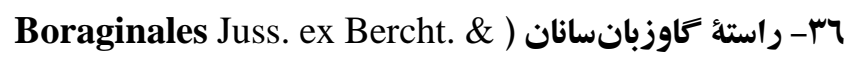
(J. Presl اين راسته داراى يكك تيره به نام كاوزبانيان ( Boraginaceae

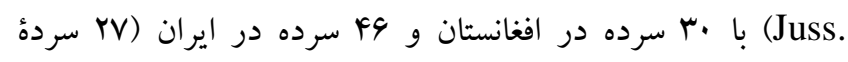

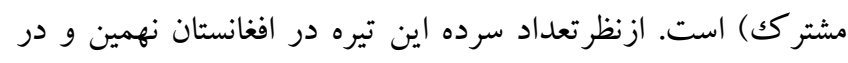

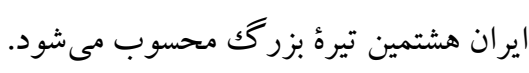

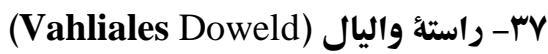
اين راسته در افغانستان عضوى ندارد و در ايران احتمالاً فقط با يكك

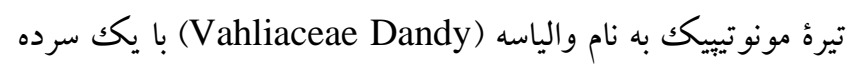
و يك كونه مى ئرويد.

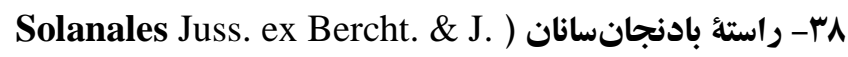
(Presl اين راسته داراى ץ تيرهُ مشترك در هر دو كشور است. اين تيرهها

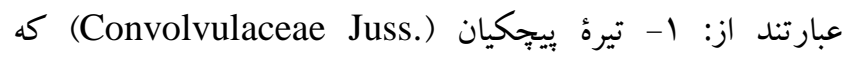

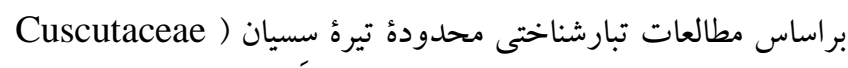

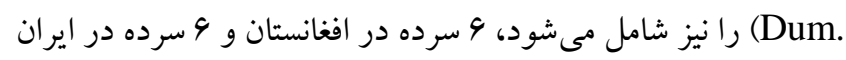

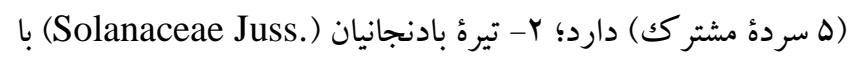

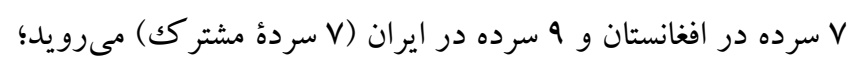

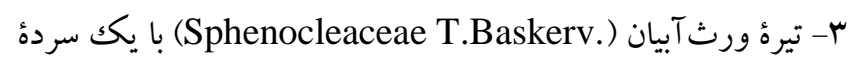

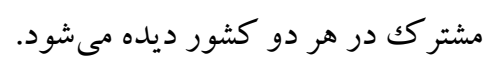


حدود وبا سرده در افغانستان و DV سرده در ايران (N•ا سرده مشتركs) بزركَترين تيره ازنظر تعداد سرده در هر دو كشور است.

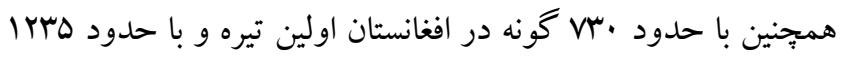
گونه در ايران دومين تيره ازنظر تعداد گونه است. سردهُ هزارخار دومين سرده بر گونه در هر دو كشور محسوب (Cousinia Cass.) مى شود.

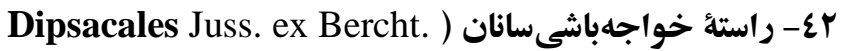

(\& J. Presl

اين راسته داراى Y تيره مشتر كك در هر دو كشور است. اين تيرهها عبارتند از: 1- تيرهُ بُداغيان (Adoxaceae E.Mey.) با r سردهُ مشترك در هر دو كشوركه هر دو بيش از اين در تيرهُ ديخر اين راسته يعنى تيره يِيج امين الدولهايان قرار مى گرفتند، حضور دارد؛ بـ تيرهُ بيجيجامين الدولهايان (Caprifoliaceae Juss) در افغانستان 9 سرده و در ايران ال سرده (N سرده مشتر كى) دارد كه يكى بيش از اين متعلق به تيره خارعروسيان (Morinaceae Agardh)، م سرده متعلق به تيرهُ سنبل الطيبيان (Valerianaceae Batsch) و 4 سرده متعلق به تيرهٔ خواجهباشيان ( Dipsacaceae Juss) بوده است. نام فارسى تيرهُ آقطيان بيش از اين براى تيره مىرفت ولى از آنجاكه سرده آقطى در حال حاضر به تيره منتقل شده است در اين مقاله براى تيره Caprifoliaceae نام بداغيان به كار مىرود و لذا در اين جا نام آقطيان به هيج تيرهاى اطلاق نشده است.

rاع- راستة كرفسسانان (Apiales Nakai) اين راسته داراى Y تيره مشترك در افغانستان و ايران است. اين تيرهها عبارتند از: ا- تيره عشقهايان (Araliaceae Juss) با r سرده در افغانستان و r سرده در اير ان (يكك سردهُ مشترك) كه يكى از آنها يميش از اين متعلق به تيرهُ ديخر اين راسته يعنى كرفسيان ( Apiaceae VA با (Apiaceae) بود، حضور دارد؛ Y- تيره كرفسيان (Lindl. سرده در افغانستان و IYF سرده در اير ان (سه سردهُ مشتر كs) يراكنده است. كرفسيان در افغانستان جهارمين و در ايران سومين تيرهُ بزرگك ازنظر تعداد سرده به شمار مىرود و با حدود .بr كونه در افغانستان
رويد؛ 9- تيره ياخرسيان (Acanthaceae Juss)، كه تيره حرائيان (Avicenniaceae Endl. ex Schnizl.) F سرده در افغانستان و س سرده متفاوت در ايران يراكنده است؛ V تيره يِيجِاناريان (Bignoniaceae Juss) با r سرده در افغانستان و يكك سرده در ايران (يكك سرده مشتركك) مىرويد؛ م- تيرهُ علفانبانيان (Lentibulariaceae Rich) با يكك سردهُ مشتر كك در هر Verbenaceae ) دو كشور ديده مىشود؛ با Y سرده مشتر كك در هر دو كشور حضور دارد؛ .1.St.Hil. تيرهُ نعنائيان (Lamiaceae Martinov) با FA سرده در افغانستان و FA تيرهُ بزرگ هر دو كشور ازنظر تعداد سرده و با حدود . FF. ينجمين تيره بزرك افغانستان و با حدود FYD Fونه جهارمين تيره: بزرگك ايران ازنظر تعداد گونه محسوب مىشود؛ ال|- تيرهُ مازاسه فقط با يك سرده در افغانستان مىرويد؛ (Mazaceae Reveal) با - تيره فريماسه (Phrymaceae Schauer) يكك سرده مشتر ك در هر دو كشور دارد كه بيش از اين متعلق به تيرهٔ (Dodartia L.) كل ميمونيان بوده است؛ سا - تيرهُ گل جاليزيان ( Orobanchaceae (Vent. دارد كه سا سرده ييش از اين در تيره كلميمونيان قرار داده مى شدند.

\section{كامِانوليدها (Campanulids)}

• ع- راستة خاسسانان (Aquifoliales Senft) اين راسته فقط در ايران با تيره خاسيان ( Aquifoliaceae و و يكك سرده و يكك گونه يافت مى شود و در افغانستان عضوى ندارد.

اع- راستة كاسنى سانان (Asterales Link) اين راسته داراى ب تيره مشترك در افغانستان و ايران است. اين تيرهها عبارتند از: ا- تيره كل استكانيان (Campanulaceae Juss) با F سرده در افغانستان و 4 سرده در ايران (Y سرده مشتركك) مى رويد؛ r - تيرهُ شبدرباتلاقيان (Menyanthaceae Dumort) يكك سرده در افغانستان و Y سرده در ايران (يكك سرده مشتركك) دارد كه بيش از اين هر دو در تيرهُ كَلسياسيان (Gentianaceae) جاى داده مى شدند؛ س- تيرهٔ كاسنيان (Asteraceae Bercht. \& J.Presl) با 
تVeselskya Opiz (Halarchon Bunge Cryptocapnos Rech.f. Bamiania Lincz.

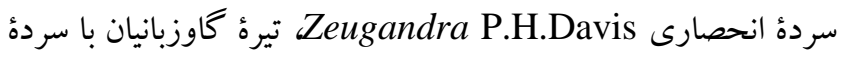
انحصارى Heliocarya Bunge و تيرء نعنائيان با سرده انحصارى Zhumeria Rech.f. \& Wendelbo

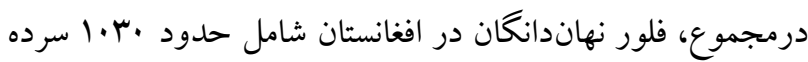

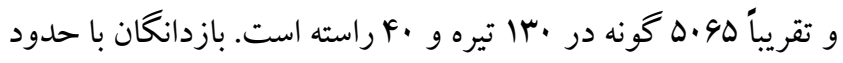

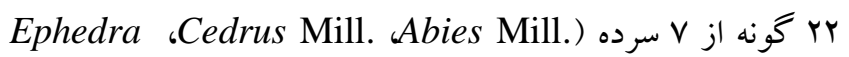
(Taxus L. gPinus L. „Picea A.Dietr. „Juniperus L. ‘L. و ץ Cupressaceae Gray, Ephedraceae Dumort., ) و (Pinaceae Spreng. ex F.Rudolphi, Taxaceae Gray نهانزادان آوندى در كل با حدود ^ه گونه از צr سرده و rا تيره در افغانستان يافت مىشوند (Breckle et al., 2013). از خزه يكك گونه شاخواش، 90 گونه جگرواش و

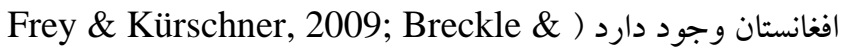
Rafiqpoor, pers. comm. بنابراين، تعداد رويانداران

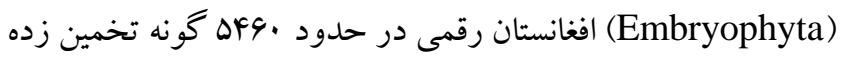
مىشود. در آخرين فهرست ارائه شده از فلور ايران (Ghahremaninejad \& Nejad Falatoury, 2016) ‘Datiscaceae ‘Ceratophyllaceae ‘Arecaceae 9 Juncaginaceae ‘Elatinaceae ‘Dioscoreaceae Ruppiaceae روزترين فهرست كلى فلور ايران به شرح زير ارائه و اصلاح مىشود

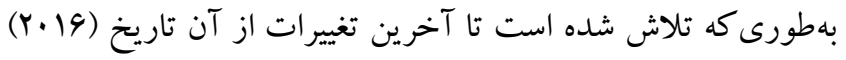
تاكنون را نيز دربر گيرد (فهرست كلى و دقيق تيرهها و سردهها در

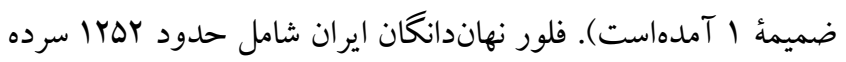

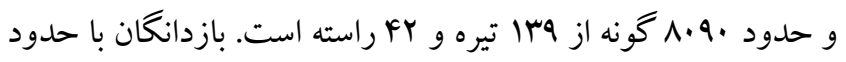

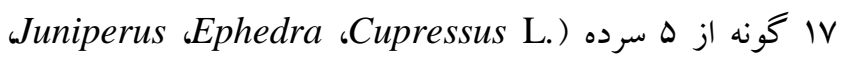
و و و ب تيره (Thuja L. و و Taxus و ونهانزادان آوندى با حدود .4 كونه در ايران براكندهاند (Taxaceae
و MVD Fونه در ايران ششمين تيرهٔ بزرگك از نظر تعداد گونه در هر دو

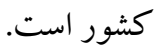
نتيجه گيرى نهايى

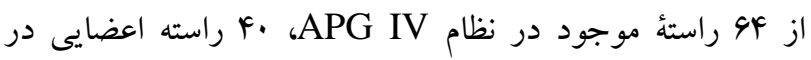

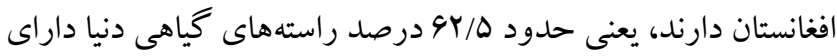
نمايندهايى در افغانستان هستند. اين نسبت در باب تيرهها حدود

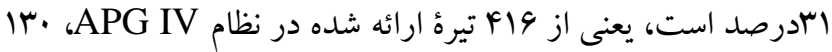
تيره حداقل با يكك گونه در افغانستان براكنش دارند. در افغانستان و ايران تيره بومويزه يا انحصارى (endemic) وجود برد

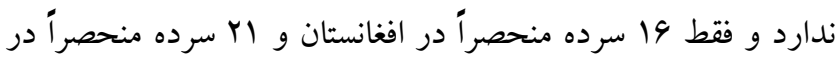
ايران مىرويند. درصد بالايى از اين سردها در هر دو كشور عضو تيره جتريان هستند كه سردهاى انحصارى از اين تيره در افغانستان Gongylotaxis Pimenov \& عبارتند از 9 سرده به نامهاى Mastigosciadium ‘Kandaharia Alava ‘Kljuykov Pyramidoptera ‘Pinacantha Gilli ‘Rech.f. \& Kuber Registaniella Rech.f. و و در ايران عبارتند از 11 سرده Azilia Hedge \& Alococarpum Riedl \& Kuber به نامهاى ‘Dicyclophora Boiss. ‘Demavendia Pimenov ،Lamond Kelussia „Kalakia Alava ‘Haussknechtia Boiss. ‘Mozaffariania Pimenov \& Maassoumi ‘Mozaff. و Rhopalosciadium Rech.f. ‘Opsicarpium Mozaff. تيرة ير تعداد بعدى با سردههاى انحصارى Sclerochorton Boiss. در افغانستان تيره: ميخكيان است با ب سرده به به نامهاى و Pentastemonodiscus Rech.f. ،Ochotonophila Gilli و ور ايران تيرة كلميان با V سرده به نام Scleranthopsis Rech.f. Dielsiocharis Acanthocardamum Thell. هاى ‘Heldreichia Boiss. ‘Elburzia Hedge ،O.E.Schulz و Straussiella Hausskn. ‘Pseudofortuynia F.Dvořák Zerdana Boiss. انحصارى دارند عبارتند از تيره كاسنيان با r سرده انحصارى TTiarocarpus Rech.f. , Chamaepus Wagenitz كلميان با r سردة انحصارى Cyphocardamum Hedge و 
جدول ا-مقايسة تعداد آرايههاى نهاندانكان در افغانستان و ايران برمبناى APG IV (درصدها ضريب شباهت زاكارد بين آرايهاى دو كشور است).

Table 1. Comparison between the number of angiosperms' taxa in Afghanistan and in Iran according to APG IV (Percents are Jaccard similarity coefficient among both countries' taxa).

$\begin{array}{lllllll} & \text { Orders } & \text { Families } & \text { Genera } & \text { Species } & \text { Endemic genera } & \text { Area }\left(\mathbf{k m}^{2}\right) \\ \text { Afghanistan } & 40 & 130 & \text { Ca. } 1030 & \text { Ca. } 5065 & 16 & 652864 \\ \text { Iran } & 42 & 139 & \text { Ca. } 1252 & \text { Ca. } 8090 & 21 & 1648195 \\ \text { Common to both countries } & 39(90 \%) & 124(86 \%) & \text { Ca. } 844(59 \%) & \text { Ca. } 1800(16 \%) & - & -\end{array}$

مساحت ايران حدود 194190190 كيلومتر مربع است كه محاسبة اين نسبتها براى ايران نشان مىدهد كه در ايران به ازاى هر .... كيلومترمربع كمتر از يكك سرده و حدود ه كونهُ نهاندانه وجود دارد (جدول (). بهعبارت ديخر، تنوع سردهها و غناى گونهاى نهاندانگًان در افغانستان نسبتاً بالاتر است و اين مطلب ضرورت مطالعات كسترده تر در زمينه تنوع زيستى رادر اين كشور نمايان مىسازد. در اين مقاله تلاش شده است تا در حد امكان از تمام منابع انتشاريافته استفاده شود و آخرين مترادفهاى آرايهها نيز مدنظر قرار

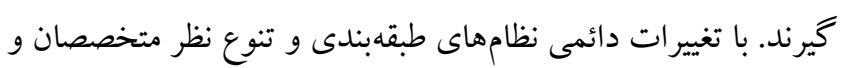
انتشار وسيع مقالات كياهشناسى، مقالهُ حاضر كه نگارش آن به عنوان جمعبنديى كلى و جديد صورت گرفته است، قاعدتاً از تغييرات و اصلاحات تكميلى در آينده بى نياز نخواهد بود. از طرفى ما نمىدانيم در افغانستان و اير ان هنوز جهه آرايههايى در انتظار كشف شدن هستند، كه اين موضوع نيز بر عدم ثبات جمعبندىهاى فلورى هر منطقه در

$$
\text { طولانى مدت تأكيد مى كند. }
$$

\section{سياسگز ارى}

نگًارند كان مراتب سياس خود را از يروفسور زيخمار بر كلى و

يروفسور داود رفيقيور براى در اختيار قراردادن دادههاى منتشرنشده در باب خزه خيان افغانستان بيان مى كنند. همجنين از يروفسور مصطفى اسدى براى مهيا ساختن دادههاى منتشر نشده در مورد نهانزادانآوندى ايران تشكر مىشود. از يروفسور احسان الشهباز براى بازخوانى و اصلاح فهرست تيرهء كلميان قدردانى مىشود. از خانم سبيده ساجدى براى نظراتشان در مورد علفهاى هرز ايران و همجنين از داوران محترم مقاله براى بيشنهادات بسيار سازنده

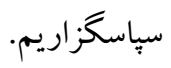

Assadi et al., 1989-2016; Azadi, 2017; ) ز).Ghahremaninejad, 1999; Khoshravesh et al., 2009

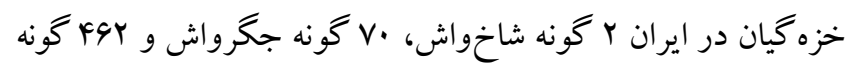
خزه يافت مىشود (Ghahremaninejad et al., 2016). بنابراين

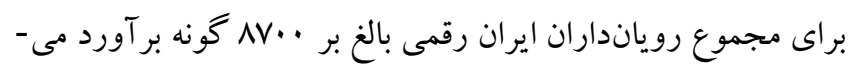
شود. از مجموع ها IFD تيرهاى كه در دو كشور مىرويند، IYF تيره مشترك است. 4 تيره فقط در افغانستان مىرويند و در ايران يافت

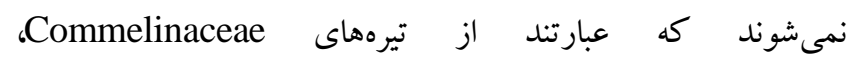
و Sapotaceae ،Melanthiaceae ،Mazaceae Eriocaulaceae Staphyleaceae و از افغانستان گزارش نشدهاند كه عبارتند از تيرههاى Apodanthaceae، 'Cistaceae 'Aristolochiaceae 'Aquifoliaceae ‘Lophiocarpaceae ‘Limeaceae ‘Cymodoceaceae ‘Nelumbonaceae ‘Molluginaceae ‘Menispermaceae 'Salvadoraceae 'Ruppiaceae 'Rhizophoraceae Vahliaceae ايران و افغانستان تيره انحصارى يافت نمىشود و اY تيرهُ نامبرده در بالا در مناطق ديخر دنيا نيز وجود دارند. تيرههاى قرهداغيان و قيجيان هردو با F سرده مشترك و تيرههاى كوشواركيان و سريشيان هر دو با م سرده مشترك شبيهترين تركيب را در بين تيرههاى دو كشور دارا هستند. در بين تيرههاى يرسرده در دو كشور كمترين ميزان اشتراك بين سردهها مربوط به تيره جتريان با وس درصد شباهت است و بيشترين شباهت مربوط به تيرهُ نعنائيان با VD درصد اشتراك است. دو تيرهُ مازريونيان و پاخرسيان با وجود دارابودن بيش از r سرده در هر كشور، هيج سرده مشتركى بين دو كشور ندارند. مساحت افغانستان

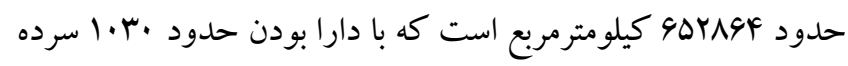

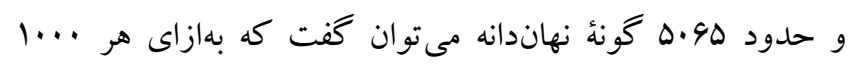
كيلومتر مربع بيش از يكك سرده و حدود ^ كونهُ نهاندانه وجود دارد. 


\section{REFERENCES}

Akhani, H. and Ghorbani, A. 2003. Mandragora turcomanica (Solanaceae) in Iran: a new distribution record for an endangered species. - Syst. Biodivers. 1: 177-180.

Akhani, H., Edwards, G. and Roalson, E.H. 2007. Diversification of the old world Salsoleae s.l. (Chenopodiaceae): molecular phylogenetic analysis of nuclear and chloroplast data sets and a revised classification. - Int. J. Plant Sci. 168: 931-956.

APG. 1998. An ordinal classification for the families of flowering plants. - Ann. Mo. Bot. Gard. 85: 531-553.

APG II. 2003. An update of the Angiosperm Phylogeny Group classification for the orders and families of flowering plants: APG II. - Bot. J. Linn. Soc. 141: 399-436.

APG III. 2009. An update of the Angiosperm Phylogeny Group classification for the orders and families of flowering plants: APG III. - Bot. J. Linn. Soc. 161: 105121.

APG IV. 2016. An update of the Angiosperm Phylogeny Group classification for the orders and families of flowering plants: APG IV. - Bot. J. Linn. Soc. 181: 1-20.

Assadi, M. et al. (eds.). 1989-2016. Flora of Iran, 1-85. RIFR, Tehran.

Azadi, R. 2017. Ferns of Iran. - In: Assadi, M. et al. (eds.): Flora of Iran. - RIFR, Tehran (in press).

Bagheri, A., Ghahremaninejad, F., Maassoumi, A.A., Rahiminejad, M.R. and Blattner, F.R. 2017. Nine new species of the species-rich genus Astragalus (Leguminosae). - Novon 25: 266-281.

Bidarlord, M., Ghahremaninejad, F. and Maassoumi, A.A. 2016. A new species of the genus Astragalus (Leguminosae) from Northwest Iran. - Phytotaxa 252: 280-284.

Breckle, S.W. and Rafiqpoor, M.D. 2010. Field guide Afghanistan: flora and vegetation. - Scientia Bonnensis, Bonn. 863pp.

Breckle, S.W., Hedge, I.C. and Rafiqpoor, M.D. 2013. Vascular plants of Afghanistan: an augmented checklist. - Scientia Bonnensis, Bonn. 598pp.

Dinarvnd, M. and Ale-Bakhit, M. 2013. Rottboellia cochinochinensis, a new weed for Iran. - Rostaniha 14: 246247.

CSO. 2012-2013. Statistical yearbook: Area and administrative and population. - Central Statistics Organization, Islamic Republic of Afghanistan; Kabul, http://cso.gov.af.

eFlora. 2017. eFlora of Pakistan. www.efloras.org (accessed 20 Feb. 2017)

Fadaie, F., Attar, F. and Ghahreman, A. 2006. A new record of Aizoaceae (Sesuvium verrucosum Raf.) for the Flora of Iran. - Iranian J. Bot. 12: 87-89.

Frey, W. and Kürschner, H. 2009. New records of bryophytes from Afghanistan - with a note on the bryological exploration of the country. - Nova Hedwigia 88: 503-511.
Ghahremaninejad, F. 1999. Flora of Gilan. Vol. 1: Pteriodophytes and Gymnosperms. - Gilan University Press, Rasht (in Persian).

Ghahremaninejad, F. 2015. Notes about Astragalus (Leguminosae) in Iran. - Ann. Naturhist. Mus. Wien, B 117: 279-281.

Ghahremaninejad, F. and Nejad Falatoury, A. 2016. An update on the flora of Iran: Iranian angiosperm orders and families in accordance with APG IV. - Nova Biol. Rep. 3: 80-107.

Ghahremaninejad, F., Joharchi, M.R., Fereidounfar, S. and Hoseini, E. 2016. Astragalus orientopersicus, sp. nov. (Fabaceae), a new taxon from the Khorassan province (Iran). - Adansonia 38: 29-33.

Ghahremaninejad, F., Shirzadian, S. and Fereidounfar, S. 2016. An updated list of the bryological literature on Iran. - Ann. Naturhist. Mus. Wien, B 118: 181=-188.

Gholipour, A. 2017. Silene oxelmanii (Caryophyllaceae), a new species from Iran. - Phytotaxa 303: 181-186.

Gholipour, A. and Golshahi, M. 2016. Two interesting annual Silene species (Caryophyllacdeae) for flora of Iran. - Nova Biol. Rep. 3: 205-209.

Gholipour, A., Sajadi, S. and Amini Rad, M. 2016. Notes on Silene chustupica, a new record and occurrence of $S$. dianthoides in Iran replacing with S. marcowiczii. Rostaniha 17: 108-114.

Hoseini, E., Ghahremaninejad, F. and Assadi, M. 2016. The indumentum of vegetative and reproductive parts of annual species of Silene (Caryophyllaceae) in Iran. Progr. Bio. Sci. 6: 107-116.

Khoshravesh, R., Akhani, H., Eskandari, M., Greuter, W. 2009. Ferns and fern allies of Iran. - Rostaniha 10 (Supplement 1).

Maassoumi, A.A. 2015. New names and new synonyms of some Astragalus species. - Iranian J. Bot. 21: 123-125.

Mirtadzadini, M., Akbari, F. and Hatami, E. 2016. Argemone (Papaveraceae), a new genus for the flora of Iran. - Iranian J. Bot. 22: 79-81.

Mozaffarian V. 2016. New species and new records from Gilan Province, Iran. - Iranian J. Bot. 22: 112-120.

Mozaffarian, V. and Yaghoubi, B. 2015. New record of Eichhornia crassipes (Water Hyacinth) from north of Iran. - Rostaniha 16: 208-211.

Pahlevani, A.H. and Sajedi, S. 2011. Alerting occurrence of several noxious weeds and invasive plants in arable lands in Iran. - Rostaniha 12: 129-134.

Podlech, D. 2012. Checklist of the flowering plants of Afghanistan. - Ludwig Maximilians University, Munich. www.sysbot.biologie.unimuenchen.de/de/ personen/podlech/flowering_plants_afghanistan.pdf

Rahiminejad, M.R., Ghaemmaghami, L. and Sahebi, J. 2004. Chenopodium pumilio (Chenopodiaceae) new to the flora of Iran. - Willdenowia 34:183-186.

Rechinger, K.H. (ed.). 1963-2015. Flora Iranica. 1-174: Akademische Druck- u. Verlagsanstalt, Graz; 175: - 
Akademische Verlagsgesellschaft, Salzburg; 176-181:Naturhistorisches Museum, Wien.

Sajedi, S. and Amini Rad, M. 2014. First report of the invasive plant Araujia from Iran. - Rostaniha 15: 7174.

Sajedi, S. and Amiri, M. 2006. Malvastrum coromandelianum, a new record for Iran. - Rostaniha 7: 95-96.

Sajedi, S., Pahlevani, A.H. and Minbashi, M. 2011. Amsinckia menziesii, first report as a weed species from Iran. - Rostaniha 12: 93-94.

Schloeder, C.A. and Jacobs, M. 2010. Afghanistan Peace Project: Afghanistan Flora: Complete plant species list. - Dept Ecosyst Science and Managem. Texas A\&M Univ. 125pp. http://is.d/NbBw7g

Terminology Departmant. 2003-2015. A collection of Terms. Vol 1-12. - The Academy of Persian Language and Literature, Tehran.

The International Plant Names Index. [Continuously updated]. www.ipni.org (accessed 10 May 2017).

The Plant List. [Continuously updated]. Version 1.1. www.theplantlist.org (accessed 10 May 2017).

Zaeifi, M. and Ramazanzade, S. 2009. Ogastemma brumitt (Boraginaceae), a new genus for the flora of Iran. - Iranian J. Bot. 15: 172-174.

Zare, H., Ramezani Kakroudi and E., Amini, T. 2007. A record of Duchesnea indica (Rosaceae) in Iran, its western most distributional limit in Asia. - Iranian J. Bot. 13: 93-94.

$$
* * * * *
$$

How to cite this article:

Ghahremaninejad, F., Ataei, N. and Nejad Falatoury, A. 2017. Comparison of angiosperm flora of Afghanistan and Iran in accordance with APG IV system. - Nova Biol. Rep. 4: 73-97.

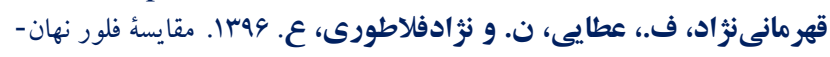
دانغان افغانستان و ايران مطابق با نظام APG IV.

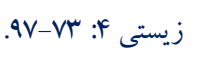




$$
\begin{aligned}
& \text { ضميمه ا - فهرست الفبايى تيرهها و سردهاى نهاندانكان افغانستان و ايران براساس نظام APG IV (سبز: تاكسونهايى كه فقط در افغانستان يافت مىشوند؛ قهوهاى: } \\
& \text { تاكسونهايى كه فقط در ايران يافت مىشوند؛ آبى: تاكسونهاى مشترك بين هر دو كشور. اعداد داخل كروشه در كنار هر راسته مربوط به شمارهُ راسته در متن است. فقط }
\end{aligned}
$$

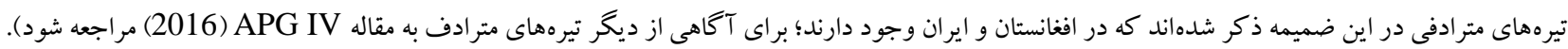

Appendix 1. Alphabetical list of angiosperm families and genera of Afghanistan and Iran in accordance with APG IV (Green: Taxa restricted to Afghanistan; Brown: Taxa restricted to Iran; Blue: Taxa shared by both countries. The number which appears before the name of each order within brackets is the number assigned to that order in the text. Only synonym

\begin{tabular}{|c|c|c|}
\hline Family & Persian family name & Genus/Genera \\
\hline $\begin{array}{l}\text { Acanthaceae (incl. } \\
\text { Avicenniaceae) } \\
\text { [39. Lamiales] }\end{array}$ & $\begin{array}{l}\text { pa.khers.iyan } \\
\text { (ياخرسيان) }\end{array}$ & Acanthus, Avicennia, Blepharis, Dicliptera, Hygrophila, Justicia, Strobilanthes \\
\hline $\begin{array}{l}\text { Acoraceae } \\
{[3 . \text { Acorales }]}\end{array}$ & 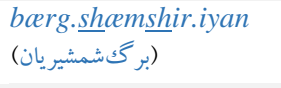 & Acorus \\
\hline $\begin{array}{l}\text { Adoxaceae } \\
\text { [42. Dipsacales] }\end{array}$ & $\begin{array}{l}\text { bodagh.iyan } \\
\text { (بداغيان) }\end{array}$ & Sambucus, Viburnum \\
\hline $\begin{array}{l}\text { Aizoaceae } \\
\text { [32. Caryophyllales] }\end{array}$ & $\begin{array}{l}\text { alaeffarsh.iyan } \\
\text { (علففرشيان) }\end{array}$ & Aizoon, Mesembryanthemum, Sesuvium, Trianthema, Zaleya \\
\hline $\begin{array}{l}\text { Alismataceae } \\
\text { [4. Alismatales] }\end{array}$ & $\begin{array}{l}\text { ghashogh.vash.iyan } \\
\text { (قاشقواشيان) }\end{array}$ & Alisma, Damasonium, Sagittaria \\
\hline $\begin{array}{l}\text { Amaranthaceae } \\
\text { (incl. } \\
\text { Chenopodiaceae) } \\
\text { [32. Caryophyllales] }\end{array}$ & $\begin{array}{l}\text { Taj.khurus.iyan } \\
\text { (تاجخروسيان) }\end{array}$ & $\begin{array}{l}\text { Achyranthes, Aerva, Agriophyllum, Alternanthera, Amaranthus, Anabasis (=Brachylepis), } \\
\text { Anthochlamys, Arthrocnemum, Atriplex, Bassia, Beta, Bienertia, Camphorosma, Caroxylon, } \\
\text { Ceratocarpus, Chenopodium (=Blitum, =Chenopodiastrum, =Oxybasis), Celosia, Climacoptera, } \\
\text { Corispermum, Cornulaca, Digera, Dysphania, Gamanthus, Girgensohnia, Hablitzia, } \\
\text { Halanthium, Halarchon, Halimocnemis, Halocharis, Halocnemum, Halogeton, Halopeplis, } \\
\text { Halostachys, Halothamnus, Haloxylon, Hammada, Horaninovia, Kali, Kalidium, Kaviria, } \\
\text { Kochia, Krascheninnikovia, Microcnemum, Noaea, Oreosalsola, Oxybasis, Panderia, } \\
\text { Petrosimonia, Physogeton, Piptoptera, Pupalia, Pyankovia, Salicornia, Salsola, Seidlitzia, } \\
\text { Spinacia, Suaeda, Turania,Xylosalsola }\end{array}$ \\
\hline $\begin{array}{l}\text { Amaryllidaceae } \\
\text { (incl. Alliaceae) } \\
\text { [7. Asparagales] }\end{array}$ & $\begin{array}{l}\text { naerges.iyan } \\
\text { (نركسيان) }\end{array}$ & Allium, Galanthus, Leucojum, Narcissus, Nectaroscordum, Sternbergia, Ungernia \\
\hline $\begin{array}{l}\text { Anacardiaceae } \\
\text { [28. Sapindales] }\end{array}$ & $\begin{array}{l}\text { peste.iyan } \\
\text { (يستهايان) }\end{array}$ & Cotinus, Pistacia, Rhus \\
\hline $\begin{array}{l}\text { Apiaceae } \\
\text { [43. Apiales] }\end{array}$ & $\begin{array}{l}\text { karaefs.iyan } \\
\text { (كرفسيان) }\end{array}$ & $\begin{array}{l}\text { Actinolema, Aethusa, Albovia, Alococarpum, Ammi, Anethum, Angelica (=Archangelica, } \\
\text { =Xanthogalum), Anisosciadium, Anthriscus, Aphanopleura, Apium, Artedia, Astrantia, } \\
\text { Astrodaucus, Aulacospermum, Azilia, Berula, Bifora, Bilacunaria, Bunium, Bupleurum, } \\
\text { Calyptrosciadium, Carum, Caucalis, Centella, Chaerophyllum, Chaetosciadium, } \\
\text { Chamaesciadium, Conioselinum, Conium, Coriandrum, Cuminum, Cymbocarpum, Daucus, } \\
\text { Demavendia, Dicyclophora, Dimorphosciadium, Diplotaenia, Dorema, Ducrosia, } \\
\text { Echinophora, Elaeosticta, Eleutherospermum, Eremodaucus, Ergocarpon, Eriocycla, } \\
\text { Eryngium, Falcaria, Ferula (=Schumannia), Ferulago, Foeniculum, Froriepia, } \\
\text { Fuernrohria, Galagania, Glaucosciadium, Glochidotheca (=Turgeniopsis), } \\
\text { Gongylosciadium, Gongylotaxis, Grammosciadium, Haussknechtia, Heptaptera, } \\
\text { Hellenocarum (=Muretia), Heracleum, Hippomarathrum, Hohenackeria, Hyalolaena, } \\
\text { Hymenidium (=Pleurospermum), Hymenolaena, Johrenia, Johreniopsis, Kalakia, } \\
\text { Kandaharia, Kelussia, Korovinia, Korshinskia, Kozlovia, Ladyginia (=Spongiosyndesmus), } \\
\text { Lagoecia, Laser, Laserpitium, Lecokia, Leutea, Levisticum, Libanotis, Ligusticum, Lisaea, } \\
\text { Lomatocarpa, Lomatopodium, Macrosciadium, Malabaila, Mastigosciadium, Mediasia, } \\
\text { Mozaffariania, Myrrhoides (=Physocaulis), Neocryptodiscus, Oedibasis, Oenanthe, } \\
\text { Oliveria, Opoidia, Opopanax, Opsicarpium, Oreocome, Orlaya, Ormopterum, } \\
\text { Ormosciadium, Parasilaus, Pastinaca, Petroedmondia, Petroselinum, Peucedanum } \\
\text { (=Cervaria), Physospermum, Pimpinella, Pinacantha, Polylophium, Prangos (=Cachrys), } \\
\text { Psammogeton, Pseudotrachydium, Pycnocycla, Pyramidoptera, Registaniella, } \\
\text { Rhabdosciadium, Rhopalosciadium, Sanicula, Scaligeria, Scandix, Sclerochorton, } \\
\text { Scrithacola, Selinum, Semenovia, Seseli, Sium, Smyrniopsis, Smyrnium, Stewartiella, } \\
\text { Stenotaenia, Szovitsia, Tetrataenium, Thecocarpus, Tordylium, Torilis, Trachydium, } \\
\text { Trachyspermum, Tricholaser, Trigonosciadium, Trinia, Turgenia, Vicatia, Zeravschania, } \\
\text { Zosima }\end{array}$ \\
\hline
\end{tabular}
families existing in Afghanistan and in Iran are mentioned in this appendix; for other synonyms, see the APG IV (2016)). 


\begin{tabular}{|c|c|c|}
\hline Family & Persian family name & Genus/Genera \\
\hline $\begin{array}{l}\text { Apocynaceae (incl. } \\
\text { Asclepiadaceae) } \\
\text { [25. Gentianales] }\end{array}$ & $\begin{array}{l}\text { khcer.zcehre.iyan } \\
\text { (خرزهرايان) }\end{array}$ & $\begin{array}{l}\text { Apocynum (=Trachomitum), Araujia, Calotropis, Caralluma, Cionura, Cynanchum, } \\
\text { Glossonema, Leptadenia, Marsdenia, Nerium, Oxystelma, Pentatropis, Pergularia, Periploca, } \\
\text { Rhazya, Vinca, Vincetoxicum }\end{array}$ \\
\hline $\begin{array}{l}\text { Apodanthaceae } \\
\text { [21. Cucurbitales] }\end{array}$ & $\begin{array}{l}\text { khun.fam.iyan } \\
\text { (خونفانيان) }\end{array}$ & Pilostyles \\
\hline $\begin{array}{l}\text { Aquifoliaceae } \\
\text { [40. Aquifoliales] }\end{array}$ & $\begin{array}{l}\text { khas.iyan } \\
\text { (خاسيان) }\end{array}$ & Ilex \\
\hline $\begin{array}{l}\text { Araceae (incl. } \\
\text { Lemnaceae) } \\
\text { [4. Alismatales] }\end{array}$ & $\begin{array}{l}\text { sheypur.iyan } \\
\text { (شيوريان) }\end{array}$ & Arisaema, Arum, Biarum, Eminium, Lemna, Spirodela, Wolffia \\
\hline $\begin{array}{l}\text { Araliaceae } \\
\text { [43. Apiales] }\end{array}$ & $\begin{array}{l}\text { ashaghe.iyan } \\
\text { (عشقهايان) }\end{array}$ & Aralia, Hedera, Hydrocotyle \\
\hline $\begin{array}{l}\text { Arecaceae } \\
\text { [8. Arecales] }\end{array}$ & $\begin{array}{l}\text { nakhhl.iyan } \\
\text { (نخليان) }\end{array}$ & Nannorrhops, Phoenix \\
\hline $\begin{array}{l}\text { Aristolochiaceae } \\
\text { [2. Piperales] }\end{array}$ & $\begin{array}{l}\text { zaravand.iyan } \\
\text { (زرانديان) }\end{array}$ & Aristolochia \\
\hline $\begin{array}{l}\text { Asparagaceae (incl. } \\
\text { Hyacinthaceae) } \\
\text { [7. Asparagales] }\end{array}$ & $\begin{array}{l}\text { marchube.iyan } \\
\text { (مارجوبهايان) }\end{array}$ & $\begin{array}{l}\text { Alrawia, Asparagus, Bellevalia, Danae, Dipcadi, Fessia, Hyacinthella, Hyacinthus, } \\
\text { Leopoldia, Muscari, Polygonatum, Puschkinia, Ruscus, Scilla, Urginea }\end{array}$ \\
\hline $\begin{array}{l}\text { Asphodelaceae (incl. } \\
\text { Xanthorrhoeaceae) } \\
\text { [7. Asparagales] }\end{array}$ & $\begin{array}{l}\text { sirish.iyan } \\
\text { (سريشيان) }\end{array}$ & Asphodeline, Asphodelus, Eremurus \\
\hline $\begin{array}{l}\text { Asteraceae } \\
\text { [41. Asterales] }\end{array}$ & $\begin{array}{l}\text { kasn.iyan } \\
\text { (كاسنيان) }\end{array}$ & $\begin{array}{l}\text { Acanthocephalus, Acantholepis, Achillea, Acroptilon, Aegopordon, Ainsliaea, Ajania, Allardia } \\
\text { (=Waldheimia), Amberboa, Amblyocarpum, Ambrosia, Anaphalis, Anacyclus, Anthemis, Anvillea, } \\
\text { Arctium, Artemisia, Aster, Asteriscus, Atractylis, Bellis, Bidens, Blumea, Bombycilaena, } \\
\text { Brachyactis, Calendula, Callicephalus, Carduus, Carlina, Carpesium, Carthamus, } \\
\text { Centaurea, Cephalorrhynchus, Chamaegeron, Chamaeleon, Chamaepus, Chardinia, } \\
\text { Chondrilla, Chrysanthemum, Cicerbita, Cichorium, Cirsium, Cnicus, Conyza, Cota, Cousinia, } \\
\text { Cousiniopsis, Crepis, Crinitaria, Crupina, Cyanus, Cymbolaena, Cynara, Dichrocephala, } \\
\text { Dipterocome, Dittrichia, Dolichorrhiza, Doronicum, Echinops, Eclipta, Epilasia, Erigeron, } \\
\text { Eupatorium, Filago, Galatella, Galinsoga, Garhadiolus, Geropogon, Gnaphalium, Grantia, } \\
\text { Gundelia, Gymnarrhena, Handelia, Hedypnois, Helichrysum, Helminthotheca, Hertia, } \\
\text { Heteracia, Heteroderis, Heteropappus, Hieracium, Hippolytia, Hyalochaete, Hymenocephalus, } \\
\text { Hypochaeris, Ifloga, Inula (=Codonocephalum), Iranecio, Ixeris, Jurinea, Jurinella, Karelinia, } \\
\text { Karvandarina, Klasea, Koelpinia, Lachnophyllum, Lactuca, Lapsana, Lasiopogon, } \\
\text { Launaea, Leontodon, Leontopodium, Lepidolopsis, Leucanthemum, Leysera, Ligularia, } \\
\text { Matricaria, Mausolea, Microcephala, Micropus, Mulgedium, Mycelis, Myopordon, } \\
\text { Myriactis, Nikitinia, Notobasis, Olgaea, Oligochaeta, Onopordum, Outreya, Pallenis, } \\
\text { Pentanema, Pertya, Petasites, Phagnalon, Picnomon, Picris, Pilostemon, Platychaete, Pluchea, } \\
\text { Polychrysum, Polytaxis, Postia, Prenanthes, Pseudognaphalium, Pseudohandelia, } \\
\text { Psychrogeton, Pterachaenia, Pulicaria (=Francoeuria), Reichardia, Rhagadiolus, Rhanterium, } \\
\text { Rhaponticum, Richteria, Russowia, Saussurea, Scariola, Schischkinia,Sclerorhachis, Scolymus, } \\
\text { Scorzonera, Senecio, Seriphidium, Serratula, Siebera, Sigesbeckia, Silybum, Solidago, Soliva, } \\
\text { Sonchus, Stemmacantha, Steptorhamphus, Symphyotrichum (=Conyzanthus), Tagetes, } \\
\text { Tanacetopsis, Tanacetum (=Spathipappus), Taraxacum, Thevenotia, Tiarocarpus, Tragopogon, } \\
\text { Trichanthemis, Tricholepis, Tripleurospermum, Turaniphytum, Tussilago, Uechtritzia, } \\
\text { Urospermum, Varthemia, Volutaria, Willemetia, Xanthium, Xeranthemum, Xylanthemum, } \\
\text { Youngia,Zoegea }\end{array}$ \\
\hline $\begin{array}{l}\text { Balsaminaceae } \\
\text { [34. Ericales] }\end{array}$ & $\begin{array}{l}\text { gole.biscebriyan } \\
\text { (كلبىصبريان) }\end{array}$ & Impatiens \\
\hline $\begin{array}{l}\text { Berberidaceae (incl. } \\
\text { Podophyllaceae) } \\
\text { [12. Ranunculales] }\end{array}$ & $\begin{array}{l}\text { zereshk.iyan } \\
\text { (زرشكيان) }\end{array}$ & Berberis, Bongardia, Gymnospermium, Epimedium, Leontice, Sinopodophyllum \\
\hline $\begin{array}{l}\text { Betulaceae (incl. } \\
\text { Corylaceae) } \\
{[20 . \text { Fagales }]}\end{array}$ & $\begin{array}{l}\text { tuska.'iyan } \\
\text { (تو سكائيان) }\end{array}$ & Alnus, Betula, Carpinus, Corylus \\
\hline $\begin{array}{l}\text { Biebersteiniaceae } \\
\text { [28. Sapindales] }\end{array}$ & $\begin{array}{l}\text { adarmak.iyan } \\
\text { (آدمكيان) }\end{array}$ & Biebersteinia \\
\hline $\begin{array}{l}\text { Bignoniaceae } \\
\text { [39. Lamiales] }\end{array}$ & $\begin{array}{l}\text { pich.cenar.iyan } \\
\text { (ييجاناريان) }\end{array}$ & Incarvillea, Tecomella \\
\hline
\end{tabular}




\begin{tabular}{|c|c|c|}
\hline Family & Persian family name & Genus/Genera \\
\hline $\begin{array}{l}\text { Boraginaceae } \\
\text { [36. Boraginales] }\end{array}$ & $\begin{array}{l}\text { gav.zaban.iyan } \\
\text { (كاوزبانيان) }\end{array}$ & $\begin{array}{l}\text { Alkanna, Amsinckia, Anchusa, Argusia, Arnebia, Asperugo, Bothriospermum, Brunnera, } \\
\text { Buglossoides, Caccinia, Cerinthe, Cordia, Cynoglossum, Echiochilon, Echium, Ehretia, } \\
\text { Eritrichium, Gastrocotyle, Heliocarya, Heliotropium, Heterocaryum, Hormuzakia, } \\
\text { Huynhia, Lappula (=Sclerocaryopsis), Lepechiniella, Lindelofia, Lithospermum, } \\
\text { Mattiastrum, Microparacaryum, Moltkia, Moltkiopsis, Myosotis, Nonea, Ogastemma, } \\
\text { Omphalodes, Onosma, Oreogenia, Paracaryum, Phyllocara, Pseudomertensia, Rindera, } \\
\text { Rochelia, Sericostoma, Solenanthus, Suchtelenia, Symphytum, Tournefortia } \\
\text { (=Messerschmidia),Trachelanthus, Trichodesma }\end{array}$ \\
\hline $\begin{array}{l}\text { Brassicaceae } \\
{[30 . \text { Brassicales] }}\end{array}$ & $\begin{array}{l}\text { kaelam.iyan } \\
\text { (كلميان) }\end{array}$ & 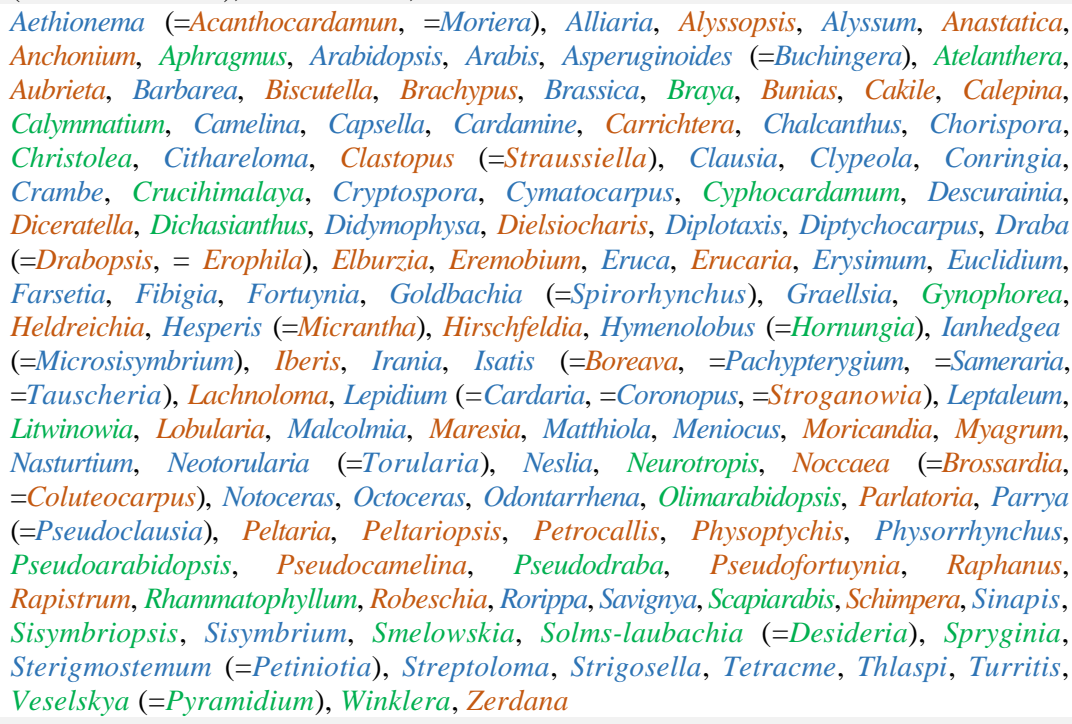 \\
\hline $\begin{array}{l}\text { Butomaceae } \\
\text { [4. Alismatales] }\end{array}$ & $\begin{array}{l}\text { hezar.ne.'iyan } \\
\text { (هزارنى ايان) }\end{array}$ & 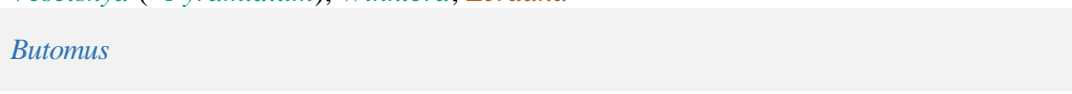 \\
\hline $\begin{array}{l}\text { Buxaceae } \\
{[14 \text {. Buxales] }}\end{array}$ & $\begin{array}{l}\underline{\text { shemshad.iyan }} \\
\text { (شماديان) }\end{array}$ & Buxus \\
\hline $\begin{array}{l}\text { Campanulaceae } \\
\text { [41. Asterales] }\end{array}$ & $\begin{array}{l}\text { gol.estekan.iyan } \\
\text { (كل استكانيان) }\end{array}$ & $\begin{array}{l}\text { Asyneuma, Campanula, Codonopsis, Legousia, Michauxia (=Mindium), Ostrowskia, } \\
\text { Symphyandra,Zeugandra }\end{array}$ \\
\hline $\begin{array}{l}\text { Cannabaceae } \\
{[19 . \text { Rosales] }}\end{array}$ & $\begin{array}{l}\text { shah.dane.'iyan } \\
\text { (شاهدانهايان) }\end{array}$ & Cannabis, Celtis, Humulus \\
\hline $\begin{array}{l}\text { Capparaceae } \\
{[30 . \text { Brassicales] }}\end{array}$ & $\begin{array}{l}\text { kabar.iyan } \\
\text { (كبريان) }\end{array}$ & Cadaba, Capparis, Maerua \\
\hline $\begin{array}{l}\text { Caprifoliaceae (incl. } \\
\text { Dipsacaceae, } \\
\text { Morinaceae } \quad \& \\
\text { Valerianaceae) } \\
\text { [42. Dipsacales] }\end{array}$ & $\begin{array}{l}\text { piche.'ceminoddole.'iyan } \\
\text { (يبج) امين الدولهايان) }\end{array}$ & $\begin{array}{l}\text { Abelia, Centranthus, Cephalaria, Dipsacus, Knautia, Lonicera, Morina, Pterocephalus, } \\
\text { Scabiosa, Scabiosiopsis, Valeriana, Valerianella }\end{array}$ \\
\hline $\begin{array}{l}\text { Caryophyllaceae } \\
\text { [32. Caryophyllales] }\end{array}$ & $\begin{array}{l}\text { mikhaek.iyan } \\
\text { (ميخكيان) }\end{array}$ & $\begin{array}{l}\text { Acanthophyllum, Agrostemma, Allochrusa, Ankyropetalum, Arenaria, Bufonia, Cerastium, } \\
\text { Cometes, Cucubalus, Dianthus, Diaphanoptera, Eremogone, Gymnocarpos, Gypsophila, } \\
\text { Habrosia, Herniaria, Holosteum, Kabulianthe, Lepyrodiclis, Loeflingia, Lychnis, } \\
\text { Mesostemma, Minuartia, Moehringia, Myosoton, Ochotonophila, Paronychia, } \\
\text { Pentastemonodiscus, Petrorhagia, Pleioneura, Polycarpaea, Polycarpon, Pseudostellaria, } \\
\text { Pteranthus, Sagina, Saponaria, Scleranthopsis, Scleranthus, Sclerocephalus, Silene, Spergula, } \\
\text { Spergularia, Sphaerocoma, Stellaria, Telephium, Vaccaria, Velezia }\end{array}$ \\
\hline $\begin{array}{l}\text { Celastraceae (incl. } \\
\text { Parnassiaceae) } \\
\text { [22. Celastrales] }\end{array}$ & $\begin{array}{l}\text { gushvarcek.iyan } \\
\text { (كوشوار كيان) }\end{array}$ & Euonymus, Gymnosporia, Parnassia \\
\hline $\begin{array}{l}\text { Ceratophyllaceae } \\
\text { [11. Ceratophyllales] }\end{array}$ & $\begin{array}{l}\text { baerg.shakh.iyan } \\
\text { (بركاخ شاخيان) }\end{array}$ & Ceratophyllum \\
\hline $\begin{array}{l}\text { Cistaceae } \\
\text { [29. Malvales] }\end{array}$ & $\begin{array}{l}\text { gol.aftab.iyan } \\
\text { (كا آفتابيان) }\end{array}$ & Cistus, Fumana, Helianthemum \\
\hline $\begin{array}{l}\text { Cleomaceae } \\
\text { [30. Brassicales] }\end{array}$ & $\begin{array}{l}\text { celaef.mar.iyan } \\
\text { (علف ماريان) }\end{array}$ & Cleome (=Buhsea), Dipterygium \\
\hline
\end{tabular}




\begin{tabular}{|c|c|c|}
\hline Family & Persian family name & Genus/Genera \\
\hline $\begin{array}{l}\text { Colchicaceae } \\
\text { [6. Liliales] }\end{array}$ & $\begin{array}{l}\text { gol.hoesraet.iyan } \\
\text { (كل حسرتيان) }\end{array}$ & Colchicum \\
\hline $\begin{array}{l}\text { Commelinaceae } \\
\text { [9. Commelinales] }\end{array}$ & $\begin{array}{l}\text { barg.bid.iyan } \\
\text { (بركبيديان) }\end{array}$ & Commelina \\
\hline $\begin{array}{l}\text { Convolvolaceae } \\
\text { (incl. Cuscutaceae) } \\
\text { [38. Solanales] }\end{array}$ & 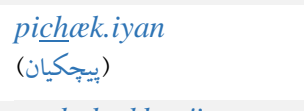 & Calystegia, Convolvulus, Cressa, Cuscuta, Evolvulus, Ipomoea, Merremia \\
\hline $\begin{array}{l}\text { Cornaceae } \\
\text { [33. Cornales] }\end{array}$ & $\begin{array}{l}\text { zoghal.akhte.'iyan } \\
\text { (ذغالاختهايان) }\end{array}$ & Cornus \\
\hline $\begin{array}{l}\text { Crassulaceae } \\
\text { [15. Saxifragales] }\end{array}$ & $\begin{array}{l}\text { golnaz.iyan } \\
\text { (كانازيان) }\end{array}$ & $\begin{array}{l}\text { Crassula, Orostachys, Pseudosedum, Rhodiola, Rosularia, Sedum, Sempervivum, } \\
\text { Umbilicus }\end{array}$ \\
\hline $\begin{array}{l}\text { Cucurbitaceae } \\
\text { [21. Cucurbitales] }\end{array}$ & $\begin{array}{l}\text { kadu.'iyan } \\
\text { (كدوئيان) }\end{array}$ & Bryonia, Citrullus, Corallocarpus, Cucumis, Ecballium, Solena \\
\hline $\begin{array}{l}\text { Cymodoceaceae } \\
\text { [4. Alismatales] }\end{array}$ & - & Halodule, Thalassodendron \\
\hline $\begin{array}{l}\text { Cynomoriaceae } \\
\text { [15. Saxifragales] }\end{array}$ & $\begin{array}{l}\text { khunin.gorz.iyan } \\
\text { (خونين خرزيان) }\end{array}$ & Cynomorium \\
\hline $\begin{array}{l}\text { Cyperaceae } \\
{[10 . \text { Poales }]}\end{array}$ & $\begin{array}{l}\text { jaggen.iyan } \\
\text { (ج) }(x)\end{array}$ & $\begin{array}{l}\text { Blysmus, Bolboschoenus, Carex, Cladium, Cyperus, Eleocharis, Eriophorum (=Erioscirpus), } \\
\text { Fimbristylis, Fuirena, Isolepis, Kobresia, Kyllinga, Pycreus, Schoenoplectiella, Schoenoplectus, } \\
\text { Schoenus, Scirpoides, Trichophorum }\end{array}$ \\
\hline $\begin{array}{l}\text { Datiscaceae } \\
\text { [21. Cucurbitales] }\end{array}$ & $\begin{array}{l}\text { shahdane.vash.iyan } \\
\text { (شاهدانهوشيان) }\end{array}$ & ( \\
\hline $\begin{array}{l}\text { Dioscoreaceae } \\
\text { [5. Dioscoreales] }\end{array}$ & $\begin{array}{l}\text { tcemis.iyan } \\
\text { (تميسيان) }\end{array}$ & Dioscorea, Tamus \\
\hline $\begin{array}{l}\text { Ebenaceae } \\
\text { [34. Ericales] }\end{array}$ & $\begin{array}{l}\text { khormalu.'iyan } \\
\text { (خرمالوئيان) }\end{array}$ & Diospyros \\
\hline $\begin{array}{l}\text { Elaeagnaceae } \\
\text { [19. Rosales] }\end{array}$ & $\begin{array}{l}\text { senjed.iyan } \\
\text { (سنجديان) }\end{array}$ & Elaeagnus, Hippophae \\
\hline $\begin{array}{l}\text { Elatinaceae } \\
\text { [24. Malpighiales] }\end{array}$ & - & Bergia, Elatine \\
\hline $\begin{array}{l}\text { Ericaceae (incl. } \\
\text { Monotropaceae \& } \\
\text { Pyrolaceae) } \\
\text { [34. Ericales] }\end{array}$ & $\begin{array}{l}\text { khoelaeng.iyan } \\
\text { (خلنخيان) }\end{array}$ & Monotropa, Orthilia, Pyrola, Vaccinium, Rhododendron \\
\hline $\begin{array}{l}\text { Eriocaulaceae } \\
\text { [10. Poales] }\end{array}$ & - & Eriocaulon \\
\hline $\begin{array}{l}\text { Euphorbiaceae } \\
\text { [24. Malpighiales] }\end{array}$ & $\begin{array}{l}\text { farfiyun.iyan } \\
\text { (فرفيونيان) }\end{array}$ & Chrozophora, Euphorbia, Mercurialis \\
\hline $\begin{array}{l}\text { Fabaceae } \\
\text { [18. Fabales] }\end{array}$ & $\begin{array}{l}\text { baghela.'iyan } \\
\text { (باقائيان) }\end{array}$ & $\begin{array}{l}\text { Anagyris, Acacia, Aeschynomene, Albizia, Alhagi, Ammodendron, Anthyllis, Argyrolobium, } \\
\text { Astragalus, Caesalpinia, Caragana, Cassia, Ceratonia, Cercis, Chesneya, Cicer, Colutea, } \\
\text { Coronilla, Crotalaria, Cullen, Dalbergia, Desmodium, Dorycnium, Ebenus, Eversmannia, } \\
\text { Galega, Genista, Gleditsia, Glycyrrhiza (=Meristotropis), Halimodendron, Hedysarum, } \\
\text { Hippocrepis, Hymenocarpus, Indigofera, Lathyrus, Lens, Lespedeza, Lotononis, Lotus, } \\
\text { Medicago, Melilotus, Mimosa, Onobrychis, Ononis, Oreophysa, Ornithopus, Oxytropis, } \\
\text { Parkinsonia, Phaseolus, Pisum, Podlechiella, Podolotus, Prosopis, Pseudolotus, Rhynchosia, } \\
\text { Scorpiurus, Securigera, Senna, Sesbania, Smirnowia, Sophora (=Ammothamnus), Spartium, } \\
\text { Sphaerophysa, Taverniera, Tephrosia, Trifolium, Trigonella, Vicia (=Faba), Vigna }\end{array}$ \\
\hline $\begin{array}{l}\text { Fagaceae } \\
\text { [20. Fagales] }\end{array}$ & $\begin{array}{l}\text { rash.iyan } \\
(\text { ) }(ر)\end{array}$ & Castanea, Fagus, Quercus \\
\hline $\begin{array}{l}\text { Frankeniaceae } \\
\text { [32. Caryophyllales] }\end{array}$ & $\begin{array}{l}\text { shabnam.iyan } \\
\text { (شبنميان) }\end{array}$ & Frankenia (=Hypericopsis) \\
\hline $\begin{array}{l}\text { Gentianaceae } \\
\text { [35. Gentianales] }\end{array}$ & $\begin{array}{l}\text { gol.sepas.iyan } \\
\text { (كلسياسيان) }\end{array}$ & $\begin{array}{l}\text { Aliopsis, Centaurium, Comastoma, Gentiana, Gentianella, Gentianopsis, Jaeschkea, } \\
\text { Kurramiana, Lomatogonium, Pleurogynella, Swertia }\end{array}$ \\
\hline $\begin{array}{l}\text { Geraniaceae } \\
\text { [25. Geraniales] }\end{array}$ & $\begin{array}{l}\text { sha'mdan.iyan } \\
\text { (شمعدانيان) }\end{array}$ & Erodium, Geranium, Monsonia, Pelargonium \\
\hline
\end{tabular}




\begin{tabular}{|c|c|c|}
\hline Family & Persian family name & Genus/Genera \\
\hline $\begin{array}{l}\text { Gisekiaceae } \\
\text { [32. Caryophyllales] }\end{array}$ & - & Gisekia \\
\hline $\begin{array}{l}\text { Grossulariaceae } \\
\text { [15. Saxifragales] }\end{array}$ & $\begin{array}{l}\text { cengur.farceng.iyan } \\
\text { (انگورفرنخيان) }\end{array}$ & Ribes \\
\hline $\begin{array}{l}\text { Haloragaceae } \\
\text { [15. Saxifragales] }\end{array}$ & $\begin{array}{l}\text { hezar.barg.iyan } \\
\text { (هزاربر گيان) }\end{array}$ & Myriophyllum \\
\hline $\begin{array}{l}\text { Hamamelidaceae } \\
\text { [15. Saxifragales] }\end{array}$ & $\begin{array}{l}\text { aenjil.iyan } \\
\text { (انجيليان) }\end{array}$ & Parrotia, Parrotiopsis \\
\hline $\begin{array}{l}\text { Hydrocharitaceae } \\
\text { (incl. Najadaceae) } \\
\text { [4. Alismatales] }\end{array}$ & $\begin{array}{l}\text { tcekht.ghurbaghe.'iyan } \\
\text { (تخت قورباغهايان) }\end{array}$ & Blyxa, Halophila, Hydrilla, Hydrocharis, Najas, Vallisneria \\
\hline $\begin{array}{l}\text { Hypericaceae } \\
\text { [24. Malpighiales] }\end{array}$ & $\begin{array}{l}\text { golra.'iyan } \\
\text { (كلراعيان) }\end{array}$ & Hypericum \\
\hline $\begin{array}{l}\text { Iridaceae } \\
\text { [7. Asparagales] }\end{array}$ & $\begin{array}{l}\text { zanbagh.iyan } \\
\text { (زنبقيان) }\end{array}$ & Crocus, Gladiolus, Moraea (=Gynandriris), Iris, Sisyrinchium \\
\hline $\begin{array}{l}\text { Ixioliriaceae } \\
\text { [7. Asparagales] }\end{array}$ & $\begin{array}{l}\text { khiarcek.iyan } \\
\text { (خيار كيان) }\end{array}$ & Ixiolirion \\
\hline $\begin{array}{l}\text { Juglandaceae } \\
\text { [20. Fagales] }\end{array}$ & $\begin{array}{l}\text { gerdu.'iyan } \\
\text { (كردوئيان) }\end{array}$ & Juglans, Pterocarya \\
\hline $\begin{array}{l}\text { Juncaceae } \\
\text { [10. Poales] }\end{array}$ & $\begin{array}{l}\text { sazu.'iyan } \\
\text { (سازوئيان) }\end{array}$ & Juncus, Luzula \\
\hline $\begin{array}{l}\text { Juncaginaceae } \\
\text { [4. Alismatales] }\end{array}$ & $\begin{array}{l}\text { se.sikhaek.iyan } \\
\text { (سيخكيان) }\end{array}$ & Triglochin \\
\hline $\begin{array}{l}\text { Lamiaceae } \\
\text { [39. Lamiales] }\end{array}$ & $\begin{array}{l}\text { na'na.'iyan } \\
\text { (نعنائيان) }\end{array}$ & $\begin{array}{l}\text { Ajuga, Ballota, Betonica, Calamintha, Chamaesphacos, Clinopodium (=Acinos), } \\
\text { Cyclotrichium, Dracocephalum, Drepanocaryum, Elsholtzia, Eriophyton, Gontscharovia, } \\
\text { Hymenocrater, Hypogomphia, Hyssopus, Isodon, Kudrjaschevia, Lagochilus, Lallemantia, } \\
\text { Lamium, Lavandula, Leonurus, Leucas, Lophanthus, Lycopus, Marrubium, Melissa, } \\
\text { Mentha, Micromeria, Moluccella, Nepeta, Ocimum, Origanum, Otostegia, Perilla, } \\
\text { Perovskia, Phlomidoschema, Phlomis, Phlomoides (=Eremostachys), Prunella, } \\
\text { Rydingia, Salvia, Satureja, Scutellaria, Sideritis, Stachyopsis, Stachys, Teucrium, } \\
\text { Thuspeinanta, Thymbra,Thymus, Vitex, Zataria,Zhumeria,Ziziphora }\end{array}$ \\
\hline $\begin{array}{l}\text { Lentibulariaceae } \\
\text { [39. Lamiales] }\end{array}$ & $\begin{array}{l}\text { alaef.cenban.iyan } \\
\text { (علف انبانيان) }\end{array}$ & Utricularia \\
\hline $\begin{array}{l}\text { Liliaceae } \\
\text { [6. Liliales] }\end{array}$ & $\begin{array}{l}\text { suscen.'iyan } \\
\text { (سوسنيان) }\end{array}$ & Erythronium, Fritillaria, Gagea, Lilium, Lloydia, Notholirion, Ornithogalum, Tulipa \\
\hline $\begin{array}{l}\text { Limeaceae } \\
\text { [32. Caryophyllales] }\end{array}$ & - & Limeum \\
\hline $\begin{array}{l}\text { Linaceae } \\
\text { [24. Malpighiales] }\end{array}$ & $\begin{array}{l}\text { katan.iyan } \\
\text { (كتانيان) }\end{array}$ & Linum \\
\hline $\begin{array}{l}\text { Linderniaceae } \\
\text { [39. Lamiales] }\end{array}$ & - & Lindernia \\
\hline $\begin{array}{l}\text { Lophiocarpaceae } \\
\text { [32. Caryophyllales] }\end{array}$ & - & Corbichonia \\
\hline $\begin{array}{l}\text { Loranthaceae } \\
\text { [31. Santalales] }\end{array}$ & $\begin{array}{l}\text { mukhor.iyan } \\
\text { (موخوريان) }\end{array}$ & Loranthus \\
\hline $\begin{array}{lr}\text { Lythraceae } & \text { (incl. } \\
\text { Punicaceae } & \& \\
\text { Trapaceae) } & \\
\text { [26. Myrtales] } & \end{array}$ & $\begin{array}{l}\text { haena.'iyan } \\
\text { (حنائيان) }\end{array}$ & Ammannia, Lawsonia, Lythrum, Punica, Rotala, Trapa \\
\hline $\begin{array}{l}\text { Malvaceae } \quad \text { (incl. } \\
\text { Tiliaceae) } \\
\text { [29. Malvales] }\end{array}$ & $\begin{array}{l}\text { paenirak.iyan } \\
\text { (ينير كيان) }\end{array}$ & $\begin{array}{l}\text { Abutilon, Alcea, Althaea, Anoda, Corchorus, Grewia, Hibiscus (=Bombyx), Kosteletzkya, } \\
\text { Lavatera, Malva, Malvalthaea, Malvastrum, Malvella, Sida, Tilia }\end{array}$ \\
\hline $\begin{array}{l}\text { Mazaceae } \\
\text { [39. Lamiales] }\end{array}$ & - & Mazus \\
\hline $\begin{array}{l}\text { Melanthiaceae } \\
\text { (incl. Trilliaceae) } \\
\text { [6. Liliales] }\end{array}$ & - & Trillium \\
\hline
\end{tabular}




\begin{tabular}{|c|c|c|}
\hline Family & Persian family name & Genus/Genera \\
\hline $\begin{array}{l}\text { Meliaceae } \\
\text { [28. Sapindales] }\end{array}$ & $\begin{array}{l}\text { zeytun.toelkh.iyan } \\
\text { (زيتون تلخيان) }\end{array}$ & Azadirachta, Melia \\
\hline $\begin{array}{l}\text { Menispermaceae } \\
\text { [12. Ranunculales] }\end{array}$ & $\begin{array}{l}\text { zamur.iyan } \\
\text { (زاموريان) }\end{array}$ & Cocculus \\
\hline $\begin{array}{l}\text { Menyanthaceae } \\
\text { [41. Asterales] }\end{array}$ & $\frac{\text { shaebdar.batlagh.iyan }}{\text { (شبرباتلاقيان) }}$ & Menyanthes, Nymphoides \\
\hline $\begin{array}{l}\text { Molluginaceae } \\
\text { [32. Caryophyllales] }\end{array}$ & $\begin{array}{l}\text { goli.naz.iyan } \\
\text { (كلىنازيان) }\end{array}$ & Glinus \\
\hline $\begin{array}{l}\text { Moraceae } \\
\text { [19. Rosales] }\end{array}$ & $\begin{array}{l}\text { tut.iyan } \\
\text { (تو تيان) }\end{array}$ & Ficus, Morus \\
\hline $\begin{array}{l}\text { Myrtaceae } \\
\text { [26. Myrtales] }\end{array}$ & $\begin{array}{l}\text { murd.iyan } \\
\text { (مورديان) }\end{array}$ & Myrtus \\
\hline $\begin{array}{l}\text { Nelumbonaceae } \\
\text { [13. Proteales] }\end{array}$ & $\begin{array}{l}\text { sce'le.baghela.iyan } \\
\text { (ثعلهباقلائيان) }\end{array}$ & Nelumbo $(=$ Nelumbium $)$ \\
\hline $\begin{array}{l}\text { Neuradaceae } \\
\text { [29. Malvales] }\end{array}$ & $\begin{array}{l}\text { tokme.shen.iyan } \\
\text { (تكمهنيان) }\end{array}$ & Neurada \\
\hline $\begin{array}{l}\text { Nitrariaceae } \\
\text { [28. Sapindales] }\end{array}$ & $\begin{array}{l}\text { ghaeraedagh.iyan } \\
(\text { قرهداغيان) }\end{array}$ & Malacocarpus, Nitraria, Peganum, Tetradiclis \\
\hline $\begin{array}{l}\text { Nyctaginaceae } \\
\text { [32. Caryophyllales] }\end{array}$ & $\begin{array}{l}\text { gol.kaghaz.iyan } \\
\text { (كل كاغذيان) }\end{array}$ & Boerhavia, Commicarpus \\
\hline $\begin{array}{l}\text { Nymphaeaceae } \\
\text { [1. Nymphaeales] }\end{array}$ & $\begin{array}{l}\text { nilufar.ab.iyan } \\
\text { (نيلوفر آبيان) }\end{array}$ & Nuphar, Nymphaea \\
\hline $\begin{array}{l}\text { Oleaceae } \\
\text { [39. Lamiales] }\end{array}$ & $\begin{array}{l}\text { zeytun.iyan } \\
\text { (زيتونيان) }\end{array}$ & Fraxinus, Jasminum, Ligustrum, Olea, Syringa \\
\hline $\begin{array}{l}\text { Onagraceae } \\
\text { [26. Myrtales] }\end{array}$ & $\begin{array}{l}\text { gol.maeghreb.iyan } \\
\text { (گل مغربيان) }\end{array}$ & Circaea, Epilobium (=Chamerion), Ludwigia, Oenothera \\
\hline $\begin{array}{l}\text { Orchidaceae } \\
\text { [7. Asparagales] }\end{array}$ & $\begin{array}{l}\text { sa'laeb.iyan } \\
\text { (ثعليان) }\end{array}$ & $\begin{array}{l}\text { Anacamptis, Cephalanthera, Comperia, Dactylorhiza, Epipactis, Eulophia, Goodyera, } \\
\text { Gymnadenia, Himantoglossum, Limodorum, Listera, Malaxis, Neottia, Ophrys, Orchis, } \\
\text { Platanthera (=Dithrix), Spiranthes, Steveniella, Zeuxine }\end{array}$ \\
\hline $\begin{array}{l}\text { Orobanchaceae } \\
\text { [39. Lamiales] }\end{array}$ & $\begin{array}{l}\text { gol.jaliz.iyan } \\
\text { (كل جاليزيان) }\end{array}$ & $\begin{array}{l}\text { Bellardia, Bungea, Cistanche, Euphrasia, Lathraea, Leptorhabdos, Lindenbergia, } \\
\text { Melampyrum, Odontites, Orobanche (=Phelipanche), Parentucellia (=Bellardia), } \\
\text { Pedicularis, Phelypaea (=Anoplon), Rhinanthus, Rhynchocorys }\end{array}$ \\
\hline $\begin{array}{l}\text { Oxalidaceae } \\
\text { [23. Oxalidales] }\end{array}$ & $\frac{\text { shaebdar.torshakk.iyan }}{\text { (شبدرترشكان) }}$ & 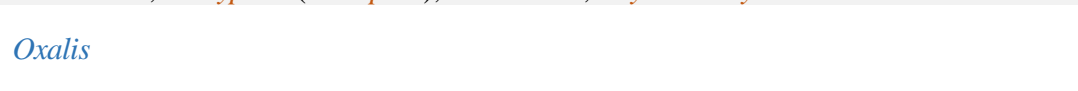 \\
\hline $\begin{array}{l}\text { Paeoniaceae } \\
\text { [15. Saxifragales] }\end{array}$ & $\begin{array}{l}\text { gol.sad.tuman.iyan } \\
\text { (كل صدتومانيان) }\end{array}$ & Paeonia \\
\hline $\begin{array}{l}\text { Papaveraceae (incl. } \\
\text { Fumariaceae) } \\
\text { [12. Ranunculales] }\end{array}$ & $\frac{\text { shaghayegh.iyan }}{\text { (شقايقيان) }}$ & $\begin{array}{l}\text { Argemone, Chelidonium, Corydalis, Cryptocapnos, Fumaria, Glaucium, Hypecoum, } \\
\text { Papaver, Roemeria }\end{array}$ \\
\hline $\begin{array}{l}\text { Pedaliaceae } \\
\text { [39. Lamiales] }\end{array}$ & $\begin{array}{l}\text { konjed.iyan } \\
\text { (كنجديان) }\end{array}$ & Sesamum \\
\hline $\begin{array}{l}\text { Phrymaceae } \\
\text { [39. Lamiales] }\end{array}$ & - & Dodartia \\
\hline $\begin{array}{l}\text { Phyllanthaceae } \\
\text { [24. Malpighiales] }\end{array}$ & $\begin{array}{l}\text { naz.biyaban.iyan } \\
\text { (نازبيابانيان) }\end{array}$ & Andrachne, Leptopus \\
\hline $\begin{array}{l}\text { Phytolaccaceae } \\
\text { [32. Caryophyllales] }\end{array}$ & $\begin{array}{l}\text { sorkhab.kowl.iyan } \\
\text { (سرخابكوليان) }\end{array}$ & Phytolacca \\
\hline $\begin{array}{l}\text { Plantaginaceae } \\
\text { (incl. } \\
\text { Callitrichaceae, } \\
\text { Globulariaceae \& } \\
\text { Hippuridaceae) } \\
\text { [39. Lamiales] }\end{array}$ & $\begin{array}{l}\text { barhoeng.iyan } \\
\text { (بارهنگگ) }\end{array}$ & $\begin{array}{l}\text { Albraunia, Bacopa, Callitriche, Chaenorhinum, Cymbalaria, Digitalis, Dopatrium, } \\
\text { Globularia, Gratiola, Hippuris, Holzneria, Kickxia, Lagotis, Limosella, Linaria, } \\
\text { Misopates, Nanorrhinum, Plantago, Schweinfurthia, Veronica, Wulfeniopsis }\end{array}$ \\
\hline
\end{tabular}




\begin{tabular}{|c|c|c|}
\hline Family & Persian family name & Genus/Genera \\
\hline $\begin{array}{l}\text { Platanaceae } \\
\text { [13. Proteales] }\end{array}$ & $\begin{array}{l}\text { chenar.iyan } \\
(\text { ) }\end{array}$ & Platanus \\
\hline $\begin{array}{l}\text { Plumbaginaceae } \\
\text { [32. Caryophyllales] }\end{array}$ & $\begin{array}{l}\text { kolahe.mir.hoesan.iyan } \\
\text { (كلامميرحسنيان) }\end{array}$ & $\begin{array}{l}\text { Acantholimon, Bamiania, Bukiniczia, Cephalorhizum, Chaetolimon, Dictyolimon, } \\
\text { Limonium, Plumbago, Popoviolimon, Psylliostachys }\end{array}$ \\
\hline $\begin{array}{l}\text { Poaceae } \\
\text { [10. Poales] }\end{array}$ & $\begin{array}{l}\text { gaendom.iyan } \\
\text { (گندميان) }\end{array}$ & $\begin{array}{l}\text { Acrachne, Aegilops (=Amblyopyrum), Aeluropus, × Agropogon, Agropyron, Agrostis, } \\
\text { Aira, Alopecurus, Ammochloa, Anthephora, Anthoxanthum, Apera, Apluda, Aristida, } \\
\text { Arrhenatherum, Arthraxon, Arundo, Avena, Beckmannia, Boissiera, Bothriochloa, } \\
\text { Brachiaria, Brachypodium (=Trachynia), Briza, Bromus, Calamagrostis, Castellia, } \\
\text { Catabrosa, Catapodium, Cenchrus, Centropodia (=Asthenatherum), Chloris, Chrysopogon, } \\
\text { Cleistogenes, Coelachyrum, Coix, Colpodium (=Catabrosella), Corynephorus, Crithopsis, } \\
\text { Crypsis, Cutandia, Cymbopogon, Cynodon, Cynosurus, Dactylis, Dactyloctenium, } \\
\text { Danthoniopsis, Deschampsia, Desmostachya, Deyeuxia, Dichanthium (=Eremopogon), } \\
\text { Digitaria, Dinebra, Duthiea, Echinaria, Echinochloa, Eleusine, Elionurus, Elymus, } \\
\text { Enneapogon, Eragrostis, Eremopoa, Eremopyrum, Eriochloa, Eulaliopsis, Festuca } \\
\text { (=Leucopoa), Fingerhuthia, Gastridium, Glyceria, Halopyrum, Helictotrichon, Hemarthria, } \\
\text { Henrardia, Heteranthelium, Heteropogon, Hierochloe, Hordelymus, Hordeum, Hyparrhenia, } \\
\text { Imperata, Isachne, Kengia, Koeleria, Lamarckia, Lasiurus, Leersia, Leptochloa, Leptothrium } \\
\text { (=Latipes), Lepturus (=Monerma, =Parapholis), Leymus, Loliolum, Lolium, } \\
\text { Melanocenchris, Melica, Microstegium, Milium, Mnesithea, Muhlenbergia, Nardurus, } \\
\text { Nephelochloa, Neyraudia, Ochthochloa, Oplismenus, Oryza, Oryzopsis, Panicum, } \\
\text { Parapholis, Paspalum, Pennisetum, Phacelurus, Phalaris, Phleum, Phragmites, } \\
\text { Piptatherum, Poa, Pogonatherum, Polypogon, Psathyrostachys, Psilurus, Puccinellia, } \\
\text { Rhizocephalus, Rostraria (=Lophochloa), Rottboellia, Saccharum, Schismus, } \\
\text { Schoenefeldia, Sclerochloa, Secale, Sesleria, Setaria, Sorghum, Sphenopus, Sporobolus, } \\
\text { Stipa, Stipagrostis, Taeniatherum, Tenaxia,Tetrapogon,Themeda,Tragus, Tricholaena, } \\
\text { Tripogon, Trisetaria, Trisetum, Triticum, Urochloa, Ventenata (=Gaudinopsis), } \\
\text { Vulpia, Zingeria }\end{array}$ \\
\hline $\begin{array}{l}\text { Polygalaceae } \\
\text { [18. Fabales] }\end{array}$ & $\begin{array}{l}\text { shiravar.iyan } \\
\text { (شير آوريان) }\end{array}$ & 有 \\
\hline $\begin{array}{l}\text { Polygonaceae } \\
\text { [32. Caryophyllales] }\end{array}$ & $\begin{array}{l}\text { celcef.haeft.band.iyan } \\
\text { (علفتبنديان) }\end{array}$ & $\begin{array}{l}\text { Aconogonon, Atraphaxis, Calligonum, Emex, Fagopyrum, Fallopia, Koenigia, Oxyria, } \\
\text { Persicaria, Polygonum, Pteropyrum, Rheum, Rumex }\end{array}$ \\
\hline $\begin{array}{l}\text { Pontederiaceae } \\
\text { [9. Commelinales] }\end{array}$ & $\begin{array}{l}\text { ghaelafiyan } \\
\text { (غلانيان) }\end{array}$ & Eichhornia, Monochoria \\
\hline $\begin{array}{l}\text { Portulacaceae } \\
\text { [32. Caryophyllales] }\end{array}$ & $\begin{array}{l}\text { khorfe.'iyan } \\
\text { (خرفهان(خان) }\end{array}$ & Portulaca \\
\hline $\begin{array}{l}\text { Potamogetonaceae } \\
\text { (incl. } \\
\text { Zannichelliaceae) } \\
\text { [4. Alismatales] }\end{array}$ & $\begin{array}{l}\text { gushab.iyan } \\
\text { (كوشابيان) }\end{array}$ & Althenia, Groenlandia, Potamogeton, Stuckenia, Zannichellia \\
\hline $\begin{array}{l}\text { Primulaceae (incl. } \\
\text { Myrsinaceae) } \\
\text { [34. Ericales] }\end{array}$ & $\begin{array}{l}\text { pamchal.iyan } \\
\text { (يامجاليان) }\end{array}$ & $\begin{array}{l}\text { Anagallis, Androsace, Cortusa, Cyclamen, Dionysia, Glaux, Lysimachia, Myrsine, } \\
\text { Primula, Samolus }\end{array}$ \\
\hline $\begin{array}{l}\text { Ranunculaceae } \\
\text { [12. Ranunculales] }\end{array}$ & $\begin{array}{l}\text { alale.'iyan } \\
\text { (آلادلايان) }\end{array}$ & $\begin{array}{l}\text { Aconitum, Actaea, Adonis, Anemone, Aquilegia, Batrachium, Callianthemum, Caltha, } \\
\text { Ceratocephala, Clematis, Consolida, Delphinium, Eranthis, Ficaria, Halerpestes, } \\
\text { Isopyrum, Myosurus, Nigella, Paraquilegia, Pulsatilla, Ranunculus, Thalictrum, Trollius }\end{array}$ \\
\hline $\begin{array}{l}\text { Resedaceae } \\
\text { [30. Brassicales] }\end{array}$ & $\begin{array}{l}\text { espaerak.iyan } \\
\text { (اسير كيان) }\end{array}$ & Ochradenus, Oligomeris, Reseda \\
\hline $\begin{array}{l}\text { Rhamnaceae } \\
\text { [19. Rosales] }\end{array}$ & $\begin{array}{l}\text { annab.iyan } \\
\text { (عنابيان) }\end{array}$ & Berchemia, Frangula, Paliurus, Rhamnus, Sageretia, Ziziphus \\
\hline $\begin{array}{l}\text { Rhizophoraceae } \\
\text { [24. Malpighiales] }\end{array}$ & 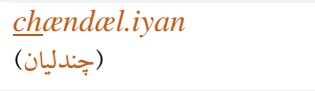 & Rhizophora \\
\hline $\begin{array}{l}\text { Rosaceae } \\
\text { [19. Rosales] }\end{array}$ & $\begin{array}{l}\text { gole.sorkh.iyan } \\
\text { (كلسرخيان) }\end{array}$ & $\begin{array}{l}\text { Agrimonia, Alchemilla, Aphanes, Aremonia, Aruncus, Cotoneaster, Crataegus, Cydonia, } \\
\text { Drymocalli, Duchesnea, Filipendula, Fragaria, Geum, Malus, Mespilus, } \\
\text { Pentaphylloides, Potentilla, Prunus (=Amygdalus, =Armeniaca, =Cerasus, } \\
\text { =Laurocerasus, =Padus, =Persica), Pyracantha, Pyrus, Rosa (=Hulthemia), Rubus, } \\
\text { Sanguisorba, Sibbaldia, Sorbaria, Sorbus, Spiraea }\end{array}$ \\
\hline
\end{tabular}




\begin{tabular}{|c|c|c|}
\hline Family & Persian family name & Genus/Genera \\
\hline $\begin{array}{l}\text { Rubiaceae (incl. } \\
\text { Theligonaceae) } \\
\text { [35. Gentianales] }\end{array}$ & $\begin{array}{l}\text { ronas.iyan } \\
\text { (روناسيان) }\end{array}$ & $\begin{array}{l}\text { Aitchisonia, Asperula, Callipeltis, Crucianella, Cruciata, Gaillonia, Galium, } \\
\text { Himalrandia, Jaubertia, Kohautia, Oldenlandia, Phuopsis, Plocama (=Putoria), } \\
\text { Pseudogaillonia, Pterogaillonia, Rubia, Sherardia, Theligonum, Valantia }\end{array}$ \\
\hline $\begin{array}{l}\text { Ruppiaceae } \\
\text { [4. Alismatales] }\end{array}$ & $\begin{array}{l}\text { shurab.iyan } \\
\text { (شورابيان) }\end{array}$ & 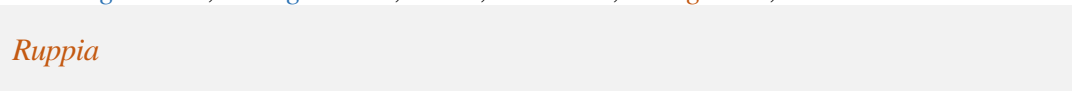 \\
\hline $\begin{array}{l}\text { Rutaceae } \\
\text { [28. Sapindales] }\end{array}$ & $\begin{array}{l}\text { sodab.iyan } \\
\text { (سدابيان) }\end{array}$ & Dictamnus, Haplophyllum, Ruta \\
\hline $\begin{array}{l}\text { Salicaceae } \\
\text { [24. Malpighiales] }\end{array}$ & $\begin{array}{l}\text { bid.iyan } \\
\text { (بيديان) }\end{array}$ & Populus, Salix \\
\hline $\begin{array}{l}\text { Salvadoraceae } \\
\text { [30. Brassicales] }\end{array}$ & $\begin{array}{l}\text { mes.vak.iyan } \\
\text { (مسواكيان) }\end{array}$ & Salvadora \\
\hline $\begin{array}{l}\text { Santalaceae } \quad \text { incl. } \\
\text { Viscaceae) } \\
\text { [31. Santalales] }\end{array}$ & $\begin{array}{l}\text { saendael.iyan } \\
\text { (صندليان) }\end{array}$ & Arceuthobium, Korthalsella, Osyris, Thesium, Viscum \\
\hline $\begin{array}{l}\text { Sapindaceae (incl. } \\
\text { Aceraceae, } \\
\text { Hippocastanaceae) } \\
\text { [28. Sapindales] }\end{array}$ & $\begin{array}{l}\text { na.taercek.iyan } \\
\text { (ناتر كيان) }\end{array}$ & Acer, Aesculus, Dodonaea, Stocksia \\
\hline $\begin{array}{l}\text { Sapotaceae } \\
\text { [34. Ericales] }\end{array}$ & - & Sideroxylon \\
\hline $\begin{array}{l}\text { Saxifragaceae } \\
\text { [15. Saxifragales] }\end{array}$ & $\begin{array}{l}\text { kharashekan.iyan } \\
\text { (خاراشكنيان) }\end{array}$ & Bergenia, Saxifraga \\
\hline $\begin{array}{l}\text { Scrophulariaceae } \\
\text { [39. Lamiales] }\end{array}$ & $\begin{array}{l}\text { gol.meymun.iyan } \\
\text { (كلميمونيان) }\end{array}$ & Buddleja, Scrophularia, Verbascum \\
\hline $\begin{array}{l}\text { Simaroubaceae } \\
\text { [28. Sapindales] }\end{array}$ & $\begin{array}{l}\text { ar.aer.iyan } \\
\text { (عرعريان) }\end{array}$ & Ailanthus \\
\hline $\begin{array}{l}\text { Smilacaceae } \\
\text { [6. Liliales] }\end{array}$ & $\begin{array}{l}\text { azmaelaek.iyan } \\
\text { (ازملكيان) }\end{array}$ & Smilax \\
\hline $\begin{array}{l}\text { Solanaceae } \\
\text { [38. Solanales] }\end{array}$ & $\begin{array}{l}\text { baden.jan.iyan } \\
\text { (بادنجانيان) }\end{array}$ & $\begin{array}{l}\text { Atropa, Datura, Hyoscyamus, Lycium, Mandragora, Physalis, Physochlaina, Solanum, } \\
\text { Withania }\end{array}$ \\
\hline $\begin{array}{l}\text { Sphenocleaceae } \\
\text { [38. Solanales] }\end{array}$ & $\begin{array}{l}\text { varaes.ab.iyan } \\
\text { (ورث آبيان) }\end{array}$ & Sphenoclea \\
\hline $\begin{array}{l}\text { Staphyleaceae } \\
\text { [27. Crossosomatales] }\end{array}$ & $\begin{array}{l}\text { khushe.iyan } \\
\text { (خوشهايان) }\end{array}$ & Staphylea \\
\hline $\begin{array}{l}\text { Tamaricaceae } \\
\text { [32. Caryophyllales] }\end{array}$ & $\begin{array}{l}\text { gaez.iyan } \\
\text { (كزيان) }\end{array}$ & Myricaria, Myrtama, Reaumuria, Tamarix \\
\hline $\begin{array}{l}\text { Thymelaeaceae } \\
\text { [29. Malvales] }\end{array}$ & $\begin{array}{l}\text { ma.zaeriyun.iyan } \\
\text { (مازريونيان) }\end{array}$ & Daphne, Dendrostellera, Diarthron, Stelleropsis, Thymelaea, Wikstroemia \\
\hline $\begin{array}{l}\text { Typhaceae (incl. } \\
\text { Sparganiaceae) } \\
\text { [10. Poales] }\end{array}$ & $\begin{array}{l}\text { lu.'iyan } \\
\text { (لوئيان) }\end{array}$ & Sparganium, Typha \\
\hline $\begin{array}{l}\text { Ulmaceae } \\
\text { [19. Rosales] }\end{array}$ & $\begin{array}{l}\text { nar.vaen.iyan } \\
\text { (نارونيان) }\end{array}$ & Ulmus, Zelkova \\
\hline $\begin{array}{l}\text { Urticaceae } \\
\text { [19. Rosales] }\end{array}$ & $\begin{array}{l}\text { ga.zane.'iyan } \\
\text { (كزنهانان) }\end{array}$ & Debregeasia, Forsskaolea, Gonostegia, Parietaria, Urtica \\
\hline $\begin{array}{l}\text { Vahliaceae } \\
\text { [37. Vahliales] }\end{array}$ & - & Vahlia \\
\hline $\begin{array}{l}\text { Verbenaceae } \\
\text { [39. Lamiales] }\end{array}$ & $\begin{array}{l}\text { shah.pasand.iyan } \\
\text { (شاهيسنديان) }\end{array}$ & Phyla, Verbena \\
\hline $\begin{array}{l}\text { Violaceae } \\
\text { [24. Malpighiales] }\end{array}$ & $\begin{array}{l}\text { baenoefshe.iyan } \\
\text { (بنشايان(ب) }\end{array}$ & Viola \\
\hline $\begin{array}{l}\text { Vitaceae } \\
\text { [16. Vitales] }\end{array}$ & $\begin{array}{l}\text { angur.iyan } \\
\text { (انكوريان) }\end{array}$ & Ampelopsis, Vitis \\
\hline
\end{tabular}




\begin{tabular}{|c|c|c|}
\hline Family & Persian family name & Genus/Genera \\
\hline $\begin{array}{l}\text { Zosteraceae } \\
\text { [4. Alismatales] }\end{array}$ & $\begin{array}{l}\text { na.var.iyan } \\
\text { (نواريان) }\end{array}$ & Zostera \\
\hline $\begin{array}{l}\text { Zygophyllaceae } \\
\text { [17. Zygophyllales] }\end{array}$ & $\begin{array}{l}\text { ghich.iyan } \\
\text { (قيجيان) }\end{array}$ & Fagonia, Seetzenia, Tribulus, Zygophyllum \\
\hline
\end{tabular}

ضميمه ب- تيرهها و راسته هاى نهاندانگان افغانستان و ايران براساس نظام APG IV به تر تيب خطى (اعداد بالانويس تيرهها: آبى: شمارؤ جلد فلورا ايرانيكا؛ قهوهاى: شمارهٔ

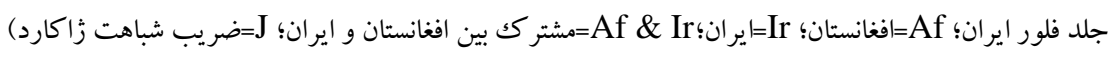

Appendix 2. Angiosperm families and orders of Afghanistan and Iran in accordance with APG IV in linear order (Superscript numbers: Blue: Volumes of Flora Iranica; Brown: Volumes of Flora of Iran; Af=Afghanistan; Ir=Iran; Af \& $\mathrm{Ir}=$ commom to Afghanintan and Iran; J=Jaccard similarity coefficient)

\begin{tabular}{|c|c|c|c|c|c|c|c|c|c|c|c|}
\hline \multirow[t]{2}{*}{ Order } & \multirow[t]{2}{*}{ Family } & \multicolumn{3}{|c|}{ Genus/genera } & \multirow[t]{2}{*}{$\mathrm{J} \%$} & \multirow[t]{2}{*}{ Order } & \multirow[t]{2}{*}{ Family } & \multicolumn{3}{|c|}{ Genus/genera } & \multirow[t]{2}{*}{$\mathrm{J} \%$} \\
\hline & & Af & Ir & $\begin{array}{l}\text { Af } \\
\& \\
\text { Ir }\end{array}$ & & & & Af & $\mathrm{Ir}$ & $\begin{array}{l}\text { Af } \\
\& \\
\text { Ir }\end{array}$ & \\
\hline Nymphaeales & Nymphaeaceae $^{33}$ & 1 & 2 & 1 & 50 & Saxifragales & Crassulaceae $^{72,32}$ & 5 & 6 & 3 & 38 \\
\hline Piperales & Aristolochiaceae $^{26,29}$ & 0 & 1 & 0 & 0 & Saxifragales & Haloragaceae $^{18,12}$ & 1 & 1 & 1 & 100 \\
\hline Acorales & Acoraceae $^{3,2}$ & 1 & 1 & 1 & 100 & Saxifragales & Cynomoriaceae $^{129}$ & 1 & 1 & 1 & 100 \\
\hline Alismatales & Araceae $^{3,119,2}$ & 5 & 6 & 4 & 57 & Vitales & Vitaceae $^{74}$ & 2 & 2 & 2 & 100 \\
\hline Alismatales & Alismataceae $^{78}$ & 2 & 3 & 2 & 67 & Zygophyllales & Zygophyllaceae $^{98,7}$ & 4 & 4 & 4 & 100 \\
\hline Alismatales & Butomaceae $^{79}$ & 1 & 1 & 1 & 100 & \multirow[t]{3}{*}{ Fabales } & \multirow{3}{*}{$\begin{array}{l}\text { Fabaceae }^{140,157,160,161,} \\
174,175,177,178,179,18,33, \\
43,45,85\end{array}$} & \multirow[t]{3}{*}{46} & \multirow[t]{3}{*}{65} & \multirow[t]{3}{*}{42} & \multirow[t]{3}{*}{61} \\
\hline Alismatales & Hydrocharitaceae ${ }^{80,86}$ & 3 & 6 & 3 & 50 & & & & & & \\
\hline Alismatales & Juncaginaceae $^{82}$ & 1 & 1 & 1 & 100 & & & & & & \\
\hline Alismatales & Zosteraceae $^{81}$ & 0 & 1 & 0 & 0 & Fabales & Polygalaceae $^{124,49}$ & 1 & 1 & 1 & 100 \\
\hline \multirow[t]{2}{*}{ Alismatales } & \multirow{2}{*}{$\begin{array}{l}\text { Potamogetonaceae }^{83}, \\
85\end{array}$} & \multirow[t]{2}{*}{3} & \multirow[t]{2}{*}{4} & \multirow[t]{2}{*}{2} & 40 & Rosales & Rosaceae $^{66,152,6}$ & 21 & 25 & 19 & 70 \\
\hline & & & & & & Rosales & Elaeagnaceae $^{55}$ & 2 & 2 & 2 & 100 \\
\hline Alismatales & Ruppiaceae $^{84}$ & 0 & 1 & 0 & 0 & Rosales & Rhamnaceae $^{125,55}$ & 5 & 5 & 4 & 67 \\
\hline Alismatales & Cymodoceaceae $^{85}$ & 0 & 2 & 0 & 0 & Rosales & Ulmaceae $^{162,4}$ & 1 & 2 & 1 & 50 \\
\hline Dioscoreales & Dioscoreaceae $^{104}$ & 1 & 1 & 0 & 0 & Rosales & Cannabaceae ${ }^{138,142,4}$ & 2 & 3 & 2 & 67 \\
\hline Liliales & Melanthiaceae $^{165}$ & 1 & 0 & 0 & 0 & Rosales & Moraceae $^{153,35}$ & 2 & 2 & 2 & 100 \\
\hline Liliales & Colchicaceae $^{165,170}$ & 1 & 1 & 1 & 100 & Rosales & Urticaceae $^{105,36}$ & 5 & 3 & 3 & 60 \\
\hline Liliales & Smilacaceae $^{165}$ & 1 & 1 & 1 & 100 & Fagales & Fagaceae $^{77}$ & 1 & 3 & 1 & 33 \\
\hline Liliales & Liliaceae $^{165}$ & 7 & 7 & 6 & 75 & Fagales & Juglandaceae $^{121}$ & 1 & 2 & 1 & 50 \\
\hline Asparagales & Orchidaceae $^{126,57}$ & 13 & 17 & 11 & 58 & Fagales & Betulaceae $e^{96,97,84}$ & 3 & 4 & 3 & 75 \\
\hline Asparagales & Ixioliriaceae $^{67,46}$ & 1 & 1 & 1 & 100 & Cucurbitales & Apodanthaceae ${ }^{136}$ & 0 & 1 & 0 & 0 \\
\hline Asparagales & Iridaceae $^{112,31}$ & 4 & 5 & 4 & 80 & Cucurbitales & Cucurbitaceae ${ }^{123,70}$ & 4 & 5 & 3 & 50 \\
\hline Asparagales & Asphodelaceae ${ }^{151,165}$ & 3 & 3 & 3 & 100 & Cucurbitales & Datiscaceae $^{29}$ & 1 & 1 & 1 & 100 \\
\hline Asparagales & Asparagaceae ${ }^{165}$ & 7 & 14 & 6 & 40 & Celastrales & Celastraceae $^{20,64}$ & 3 & 3 & 3 & 100 \\
\hline Asparagales & Amaryllidaceae $^{67,}, 76$, & 2 & 7 & 2 & 29 & Oxalidales & Oxalidaceae ${ }^{40,82}$ & 1 & 1 & 1 & 100 \\
\hline & & & & & & Malpighiales & Rhizophoraceae $^{166,80}$ & 0 & 1 & 0 & 0 \\
\hline Arecales & Arecaceae $^{146}$ & 1 & 2 & 1 & 50 & Malpighiales & Hypericaceae ${ }^{49,27}$ & 1 & 1 & 1 & 100 \\
\hline Commelinales & Commelinaceae $^{132}$ & 1 & 0 & 0 & 0 & Malpighiales & Elatinaceae $^{16}$ & 1 & 2 & 1 & 50 \\
\hline Commelinales & Pontederiaceae $^{167}$ & 1 & 2 & 1 & 50 & Malpighiales & Violaceae $^{169,5}$ & 1 & 1 & 1 & 100 \\
\hline Poales & Typhaceae $e^{59,71,42}$ & 2 & 2 & 2 & 100 & Malpighiales & Salicaceae ${ }^{65,74}$ & 2 & 2 & 2 & 100 \\
\hline Poales & Eriocaulaceae $^{89}$ & 1 & 0 & 0 & 0 & Malpighiales & Euphorbiaceae $^{6}$ & 2 & 3 & 2 & 75 \\
\hline Poales & Cyperaceae $^{173,71}$ & 17 & 16 & 15 & 83 & Malpighiales & Linaceae $^{106,34}$ & 1 & 1 & 1 & 100 \\
\hline Poales & Juncaceae $^{75,10}$ & 2 & 2 & 2 & 100 & Malpighiales & Phyllanthaceae $^{6}$ & 2 & 1 & 1 & 50 \\
\hline Poales & Poaceae $^{70}$ & 116 & 130 & 97 & 65 & Geraniales & Geraniaceae $^{69,62}$ & 2 & 4 & 2 & 50 \\
\hline Ceratophyllales & Ceratophyllaceae $^{28}$ & 1 & 1 & 1 & 100 & Myrtales & Lythraceae $^{22,51,127,67}$, & 4 & 6 & 4 & 67 \\
\hline Ranunculales & Papaveraceae $^{34,110}$ & 7 & 8 & 6 & 67 & & & & & & \\
\hline Ranunculales & Menispermaceae $^{137}$ & 0 & 1 & 0 & 0 & Myrtales & Onagraceae $^{7,50}$ & 4 & 4 & 4 & 100 \\
\hline Ranunculales & Berberidaceae $^{101,} \quad 111$, & 5 & 4 & 3 & 50 & Myrtales & Myrtaceae $^{32}$ & 1 & 1 & 1 & 100 \\
\hline & & & & & & Crossosomatales & Staphyleaceae $^{87}$ & 1 & 0 & 0 & 0 \\
\hline Ranunculales & Ranunculaceae $^{171}$ & 22 & 21 & 20 & 87 & Sapindales & Biebersteiniaceae $^{69,62}$ & 1 & 1 & 1 & 100 \\
\hline Proteales & Nelumbonaceae $^{33}$ & 0 & 1 & 0 & 0 & Sapindales & Nitrariaceae $e^{98,7}$ & 4 & 4 & 4 & 100 \\
\hline Proteales & Platanaceae $^{21}$ & 1 & 1 & 1 & 100 & Sapindales & Anacardiaceae $^{63,3}$ & 2 & 3 & 2 & 67 \\
\hline Buxales & Buxaceae $^{27}$ & 1 & 1 & 1 & 100 & Sapindales & Sapindaceae $^{38,61}$ & 4 & 3 & 3 & 75 \\
\hline Saxifragales & Paeoniaceae ${ }^{171}$ & 1 & 1 & 1 & 100 & Sapindales & Rutaceae $^{36,60}$ & 2 & 3 & 2 & 67 \\
\hline Saxifragales & Hamamelidaceae $^{53}$ & 1 & 1 & 0 & 0 & Sapindales & Simaroubaceae $^{181}$ & 1 & 1 & 1 & 100 \\
\hline Saxifragales & Grossulariaceae $^{47,23}$ & 1 & 1 & 1 & 100 & Sapindales & Meliaceae $^{133}$ & 1 & 2 & 1 & 50 \\
\hline Saxifragales & Saxifragaceae ${ }^{42,12}$ & 2 & 1 & 1 & 50 & Malvales & Neuradaceae $^{66,6}$ & 1 & 1 & 1 & 100 \\
\hline
\end{tabular}




\begin{tabular}{|c|c|c|c|c|c|c|c|c|c|c|c|}
\hline \multirow[t]{2}{*}{ Order } & \multirow[t]{2}{*}{ Family } & \multicolumn{3}{|c|}{ Genus/genera } & \multirow[t]{2}{*}{$\mathrm{J} \%$} & \multirow[t]{2}{*}{ Order } & \multirow[t]{2}{*}{ Family } & \multicolumn{3}{|c|}{ Genus/genera } & \multirow[t]{2}{*}{$\mathrm{J} \%$} \\
\hline & & Af & $\mathrm{Ir}$ & $\begin{array}{l}\text { Af } \\
\& \\
\text { Ir }\end{array}$ & & & & Af & Ir & $\begin{array}{l}\text { Af } \\
\& \\
\text { Ir }\end{array}$ & \\
\hline Malvales & Malvaceae $^{120,148,58}$ & 8 & 15 & 8 & 53 & \multirow[t]{2}{*}{ Gentianales } & \multirow{2}{*}{ Apocynaceae $_{41}^{73,103,28,}$} & \multirow{2}{*}{12} & \multirow[t]{2}{*}{17} & \multirow[t]{2}{*}{12} & \multirow[t]{2}{*}{71} \\
\hline Malvales & Thymelaeaceae $^{95,15}$ & 6 & 5 & 5 & 83 & & & & & & \\
\hline Malvales & Cistaceae $^{46,69}$ & 0 & 3 & 0 & 0 & Boraginales & Boraginaceae $^{48,39}$ & 30 & 46 & 27 & 55 \\
\hline Brassicales & Salvadoraceae $^{37,79}$ & 0 & 1 & 0 & 0 & Vahliales & Vahliaceae $^{23}$ & 0 & 1 & 0 & 0 \\
\hline Brassicales & Resedaceae $^{149}$ & 1 & 3 & 1 & 33 & Solanales & Convolvulaceae $e^{1,8,40}$ & 6 & 6 & 5 & 71 \\
\hline Brassicales & Capparaceae $^{68,30}$ & 1 & 3 & 1 & 33 & Solanales & Solanaceae ${ }^{100,24}$ & 7 & 9 & 7 & 78 \\
\hline Brassicales & Cleomaceae $^{68,30}$ & 1 & 2 & 1 & 50 & Solanales & Sphenocleaceae $^{88}$ & 1 & 1 & 1 & 100 \\
\hline Brassicales & Brassicaceae $^{57}$ & 83 & 98 & 61 & 51 & Lamiales & Oleaceae $^{52,48}$ & 4 & 5 & 4 & 80 \\
\hline Santalales & Santalaceae ${ }^{116,155,73}$ & 3 & 4 & 2 & 40 & \multirow[t]{2}{*}{ Lamiales } & \multirow{2}{*}{$\begin{array}{l}\text { Plantaginaceae } \\
118,147,180,14,68\end{array}$} & \multirow[t]{2}{*}{16} & \multirow[t]{2}{*}{19} & \multirow[t]{2}{*}{14} & \multirow[t]{2}{*}{67} \\
\hline Santalales & Loranthaceae $^{116,72}$ & 1 & 1 & 1 & 100 & & & & & & \\
\hline Caryophyllales & Frankeniaceae $^{99,11}$ & 1 & 1 & 1 & 100 & \multirow[t]{2}{*}{ Lamiales } & \multirow{2}{*}{$\begin{array}{l}\text { Scrophulariaceae } \\
68\end{array}$} & \multirow[t]{2}{*}{3} & \multirow[t]{2}{*}{2} & \multirow[t]{2}{*}{2} & 67 \\
\hline Caryophyllales & Tamaricaceae $^{14}$ & 4 & 3 & 3 & 75 & & & & & & \\
\hline Caryophyllales & Plumbaginaceae ${ }^{108,51}$ & 8 & 6 & 4 & 40 & Lamiales & Linderniaceae $^{147,68}$ & 1 & 1 & 1 & 100 \\
\hline Caryophyllales & Polygonaceae $^{56}$ & 12 & 9 & 8 & 62 & Lamiales & Pedaliaceae $^{128}$ & 1 & 1 & 1 & 100 \\
\hline Caryophyllales & Caryophyllaceae ${ }^{144,}$ & 33 & 39 & 25 & 53 & Lamiales & Acanthaceae $24,131,78$ & 4 & 3 & 0 & 0 \\
\hline & 163,65 & & & & & Lamiales & Bignoniaceae $^{44}$ & 2 & 1 & 1 & 50 \\
\hline Caryophyllales & Amaranthaceae $\mathrm{e}^{91,} \quad 172$, & 52 & 54 & 47 & 80 & Lamiales & Lentibulariaceae $^{58}$ & 1 & 1 & 1 & 100 \\
\hline & 38,75 & & & & & Lamiales & Verbenaceae $^{43,52}$ & 2 & 2 & 2 & 100 \\
\hline Caryophyllales & Limeaceae $^{114,53}$ & 0 & 1 & 0 & 0 & Lamiales & Lamiaceae $^{43,150,76}$ & 48 & 48 & 41 & 75 \\
\hline Caryophyllales & Lophiocarpaceae $^{114}$ & 0 & 1 & 0 & 0 & Lamiales & Mazaceae $^{147}$ & 1 & 0 & 0 & 0 \\
\hline Caryophyllales & Gisekiaceae $^{114,53}$ & 1 & 1 & 1 & 100 & Lamiales & Phrymaceae $^{147,68}$ & 1 & 1 & 1 & 100 \\
\hline Caryophyllales & Aizoaceae $^{113,44}$ & 2 & 5 & 2 & 40 & Lamiales & Orobanchaceae $^{5,147,68}$ & 7 & 15 & 7 & 47 \\
\hline Caryophyllales & Phytolaccaceae $^{35}$ & 1 & 1 & 1 & 100 & Aquifoliales & Aquifoliaceae $^{25}$ & 0 & 1 & 0 & 0 \\
\hline Caryophyllales & Nyctaginaceae $^{115,26}$ & 1 & 2 & 1 & 50 & Asterales & Campanulaceae $^{13,66}$ & 4 & 6 & 2 & 25 \\
\hline Caryophyllales & Molluginaceae $^{114,53}$ & 0 & 1 & 0 & 0 & Asterales & Menyanthaceae $^{41,17}$ & 1 & 2 & 1 & 50 \\
\hline Caryophyllales & Portulacaceae ${ }^{117}$ & 1 & 1 & 1 & 100 & Asterales & Asteraceae $^{90,} \quad 122, \quad 139 a$, & 136 & 157 & 108 & 58 \\
\hline Cornales & Cornaceae $^{54,83}$ & 1 & 1 & 1 & 100 & & $139 \mathrm{~b}, 145,154,158,164,59,77$ & & & & \\
\hline Ericales & Balsaminaceae $^{143}$ & 1 & 1 & 1 & 100 & Dipsacales & Adoxaceae $^{10,13}$ & 2 & 2 & 2 & 100 \\
\hline Ericales & Sapotaceae $^{159}$ & 1 & 0 & 0 & 0 & Dipsacales & Caprifoliaceae $^{10,62,168,}$ & 9 & 11 & 8 & 67 \\
\hline Ericales & Ebenaceae $^{30}$ & 1 & 1 & 1 & 100 & & & & & & \\
\hline Ericales & Primulaceae $e^{9,25}$ & 9 & 9 & 8 & 80 & Apiales & Araliaceae $^{102,162,54}$ & 2 & 2 & 1 & 33 \\
\hline Ericales & Ericaceae $^{11,93,94}$ & 2 & 4 & 1 & 20 & Apiales & Apiaceae ${ }^{162,54}$ & 78 & 124 & 53 & 36 \\
\hline Gentianales & Rubiaceae $^{39,176}$ & 14 & 18 & 13 & 68 & & & & & & \\
\hline Gentianales & Gentianaceae $^{41,16}$ & 11 & 5 & 5 & 46 & & & & & & \\
\hline
\end{tabular}

